\title{
Wave-induced watertable fluctuations, sediment transport and beach profile change: Modeling and comparison with large-scale laboratory experiments
}

\author{
R. Bakhtyar *1, A. Brovelli 1, D.A. Barry ${ }^{1}$, L. Li ${ }^{2}$
}

${ }^{1}$ Laboratoire de technologie écologique, Institut d'ingénierie de l'environnement, Faculté de l'environnement naturel, architectural et construit, Station 2, Ecole polytechnique fédérale de Lausanne (EPFL), CH-1015

Lausanne, Switzerland. Emails: roham.bakhtyar@epfl.ch, alessandro.brovelli@epfl.ch, andrew.barry@epfl.ch

2 School of Civil Engineering, University of Queensland, Queensland, Australia. Email: l.li@uq.edu.au

Revision submitted to Coastal Engineering, 20 July 2010 
ABSTRACT: Coastal groundwater systems can have a considerable impact on sediment transport and foreshore evolution in the surf and swash zones. Process-based modeling of wave motion on a permeable beach taking into account wave-aquifer interactions was conducted to investigate the effects of the unconfined coastal aquifer on beach profile evolution, and wave shoaling on the watertable. The simulation first dealt with wave breaking and wave runup/rundown in the surf and swash zones. Nearshore hydrodynamics and wave propagation in the cross-shore direction were simulated by solving numerically the two-dimensional Navier-Stokes equations with a $k$ - $\varepsilon$ turbulence closure model and the Volume-Of-Fluid technique. The hydrodynamic model was coupled to a groundwater flow model based on SEAWAT-2000, the latter describing groundwater flow in the unconfined coastal aquifer. The combined model enables the simulation of wave-induced watertable fluctuations and the effects of infiltration/exfiltration on nearshore sediment transport. Numerical results of the coupled ocean/aquifer simulations were found to compare well with experimental measurements. Wave breaking and infiltration/exfiltration increase the hydraulic gradient across the beachface and enhance groundwater circulation inside the porous medium. The large hydraulic head gradient in the surf zone leads to infiltration across the beachface before the breaking point, with exfiltration taking place below the breaking point. In the swash zone, infiltration occurs at the upper part of the beach and exfiltration at the lower part. The simulations confirm that beaches with a low watertable tend to be accreted while those with a high watertable tend to be eroded.

Keywords: Beach groundwater; infiltration/exfiltration; foreshore evolution; nearshore hydrodynamics; groundwater flow. 


\begin{tabular}{|ll|}
\hline Abbreviations & \\
NLSWE & Non-Linear Shallow Water Equation \\
NS & Navier-Stokes \\
RANS & Reynolds-Averaged Navier-Stokes \\
RMSE & Root Mean Square Error \\
SWL & Still Water Level \\
TKE & Turbulent Kinetic Energy \\
VOF & Volume-Of-Fluid \\
\hline
\end{tabular}

\begin{tabular}{|c|c|c|}
\hline \multicolumn{3}{|c|}{ Nomenclature } \\
\hline Variable & Description & Dimensions \\
\hline$d$ & local still water depth & [L] \\
\hline$D_{50}$ & $50^{\text {th }}$ percentile of the sediment diameter distribution & {$[\mathrm{L}]$} \\
\hline$f$ & friction factor & {$[-]$} \\
\hline$F$ & fluid volume per cell volume & {$[-]$} \\
\hline$g$ & magnitude of gravitational acceleration & {$\left[\mathrm{LT}^{-2}\right]$} \\
\hline$h$ & hydraulic head & {$[\mathrm{L}]$} \\
\hline$H$ & water wave height & {$[\mathrm{L}]$} \\
\hline$k$ & turbulent kinetic energy & {$\left[\mathrm{L}^{2} \mathrm{~T}^{-2}\right]$} \\
\hline$K$ & hydraulic conductivity & {$\left[\mathrm{LT}^{-1}\right]$} \\
\hline$L$ & model size & {$[\mathrm{L}]$} \\
\hline$n$ & sediment porosity & {$\left[\mathrm{L}^{3} \mathrm{~L}^{-3}\right]$} \\
\hline$P$ & pressure & {$\left[\mathrm{ML}^{-1} \mathrm{~T}^{-2}\right]$} \\
\hline$p_{r}$ & rate of turbulent kinetic energy production & {$\left[\mathrm{L}^{2} \mathrm{~T}^{-3}\right]$} \\
\hline$q_{s}$ & flow rate per unit volume of aquifer of the source or sink & {$\left[\mathrm{LT}^{-1}\right]$} \\
\hline$Q_{b}$ & sediment transport rate per unit width & {$\left[\mathrm{L}^{2} \mathrm{~T}^{-1}\right]$} \\
\hline$R$ & effective bed roughness & {$[\mathrm{L}]$} \\
\hline$s$ & specific weight of the sediment & {$\left[\mathrm{ML}^{-3}\right]$} \\
\hline$S$ & aquifer storage coefficient & {$\left[\mathrm{L}^{-1}\right]$} \\
\hline$t$ & time & {$[\mathrm{T}]$} \\
\hline
\end{tabular}




\begin{tabular}{|lll|}
\hline$T$ & wave period & {$[\mathrm{T}]$} \\
$V$ & $x$ and $y$ components of the flow velocity in the ocean & {$\left[\mathrm{LT}^{-1}\right]$} \\
$W$ & pore water velocity & {$\left[\mathrm{LT}^{-1}\right]$} \\
$X, y$ & vertical Darcy velocity in the aquifer & {$\left[\mathrm{LT}^{-1}\right]$} \\
Greek & horizontal and vertical directions & {$[\mathrm{L}]$} \\
$\beta$ & & \\
$\rho$ & local beach slope & {$[-]$} \\
$\mu$ & fluid density & {$\left[\mathrm{ML}^{-3}\right]$} \\
$v$ & dynamic viscosity & {$\left[\mathrm{ML}^{-1} \mathrm{~T}^{-1}\right]$} \\
$\varepsilon$ & kinematic viscosity & {$\left[\mathrm{L}^{2} \mathrm{~T}^{-1}\right]$} \\
$\theta$ & turbulence dissipation rate & {$\left[\mathrm{L}^{2} \mathrm{~T}^{-3}\right]$} \\
$\tau$ & Shields parameter & {$[-]$} \\
\hline
\end{tabular}

\section{Introduction}

The surf and swash zones are active and dynamic environments where a number of interconnected processes take place. The morphologies of the shoreline, beachface and seabed are continuously modified by sediment transport resulting from wave propagation and breaking, nearshore currents and interactions between ocean and coastal groundwater. These nearshore hydrodynamic processes have been studied traditionally considering an impermeable beach. However, it is now widely recognized that beach groundwater regimes can have a significant impact on sediment transport and beach stability, e.g., when infiltration and exfiltration across the bed modulating various driving mechanisms for sediment transport (Turner and Masselink, [1]).

The beach groundwater system is a highly dynamic, shallow, typically unconfined aquifer in which flow direction and magnitude is controlled by the water density contrast and water elevation at the land- and sea-ward boundaries. Both boundaries are time-dependent and fluctuate over a range of time scales. The inward groundwater elevation shows low frequency variations, typically at the seasonal time scale, whereas the sea level changes have higher frequencies, from tides (diurnal time scale) to waves (seconds). Groundwater dynamics influence the nearshore hydrodynamics through water exchange across the beachface. These exchange fluxes may in turn enhance or decrease sediment accretion on the beach (Li et al., [2]; Horn and Li, [3]). Despite the importance of groundwater elevation on beachface sediment deposition and suspension, attempts to modify beach morphology and erosion rates by controlling groundwater levels (e.g., beach drainage) have had mixed success (Horn, [31]). Failures can be attributed to the complex interactions between wave propagation and groundwater, which lead to uncertainties in field observations regarding the influence of in/exfiltration on sediment transport. A reliable quantitative analysis of the hydrodynamic processes taking place at the boundary between groundwater and seawater, 
including the rates and directions of sediment transport, has yet to be fully developed. In this respect, only a few numerical studies have been conducted, most of which use relatively strong simplifying assumptions. In order to predict the temporal evolution of beach morphology with reasonable accuracy and to understand the key processes governing the transport of sediments, comprehensive numerical models are needed to investigate the in/exfiltration and their interactions with breaking waves and swash motions. These tools should be able to account for the different facets of the surf and swash zones, viz. bed slope, in/exfiltration, turbulence, and mechanisms that induce modifications of the sediment effective weight and of the boundary layer (Elfrink and Baldock, [4]; Bakhtyar et al., [5]).

Sediment deposition is usually enhanced when the level of the beach watertable is lower than the sea level, while higher groundwater level may intensify beach erosion (Li et al., [6]). The magnitude of the fluxes across the beachface is controlled by the hydraulic conductivity of the sand and the local hydraulic gradient. Hydraulic conductivity, which depends on the porous medium and the fluid (e.g., Hensley and Barry [7]), varies in space but has a negligible dependence on time for rigid media, while the hydraulic gradient can change rapidly both in space and time. For example, as a wave front moves towards the shore, it becomes steeper. Since the local gradient depends on the elevation of the sea surface, a rise of the wave front results in a progressive increase of the hydraulic gradient and enhances the infiltration and exfiltration across the beachface (Li and Barry, [8]). In turn, the vertical flow exerts a seepage force on sediment grains within the bed, which is proportional to the hydraulic gradient. Overall, in/exfiltration through the beach surface varies during runup and backwash depend on the groundwater level and beach permeability.

The in/exfiltration effects on nearshore zone sediment transport are due to two mechanisms: effective weight modification and boundary layer thickening or thinning (Turner and Masselink, [1]). Infiltration modifies the boundary layer and increases the shear stress by constricting streamlines near the bed. Infiltration exerts a stabilizing force on the sediment particles. Conversely, exfiltration thickens the boundary layer and hence decreases the shear stress at the bed, at the same time destabilizing the bed and enhancing bed fluidization (via decreasing the effective weight) by exerting an upward force on sand grains (Turner and Masselink, [1]). The counter-balance between the two mechanisms controls the net effect of in/exfiltration on sediment transport and beach profile changes.

Groundwater heads in coastal aquifers fluctuate in response to oceanic fluctuations, including low-frequency tides and high-frequency waves (Li et al., [6,9]). Most previous investigations concerned with the modeling of the interactions between surface water with beach groundwater focused on tide-induced watertable fluctuations only, neglecting the high-frequency oscillations (Nielsen, [10]; Baird and Horn, [11]; Li et al., [12]; Guo et al. [13]). Traditionally, modeling of the groundwater response to oceanic fluctuations has been based on the Boussinesq approximation of the groundwater flow equation, which assumes negligible vertical flow (Li et al., [9]). This model can be deduced from the governing groundwater flow equations but its validity near boundaries where vertical flow can occur is limited (Barry et al. [14]; Parlange et al. [15]). A number of recent works investigated the impact of tidal fluctuations on both horizontal and vertical pore water flows in the nearshore aquifer, and the subsequent effect on solute transport (Destouni and Prieto, [16]; Smith, [17]; Vandenbohede and Lebbe, [18]; Mao et al., [19]; Robinson et al., [20,22]; Brovelli et al., [21]).

The effect of wave motion on the sedimentation process has been more thoroughly investigated, and several numerical models developed to perform quantitative analysis of the 
wave-induced motion on the beachface (e.g., Li and Barry, [8]; Kobayashi and Wurjanto, [23]). Recent field observations from exposed coasts have shown that wave forcing can also have a non-negligible impact on the aquifer circulation (Cartwright et al., [24]), which in turn may affect sediment transport and beach profile changes. Masselink and Li [25] developed a process-based numerical model to examine in detail the role of swash infiltration in determining the beachface gradient. They found that swash infiltration increases the onshore asymmetry in the swash flow and enhances the landward sediment transport. Butt et al. [26] summarized and discussed the importance of the interactions between groundwater flow and wave motion, including in/exfiltration velocities and internal pressure distribution, effect of capillary fringe on the groundwater table elevation, and importance of the through-bed flow on the sediment transport in the swash zone. Li et al. [27] developed a modified kinematic boundary condition for the watertable, which takes account of the capillary effects.

Such a complex nearshore system as described above, involving strong surface and subsurface water interactions, presents a great challenge for numerical modelers. Two different approaches have been used to compute the wave motion with a permeable bed. One approach uses the Boussinesq equations, as in Karambas [28,29]. The second method is instead based on the Non-Linear Shallow Water Equation (NLSWE), used for example by Li et al. [6] and Hoque and Asano [30]. Karambas [28] modeled in/exfiltration effects on crossshore sediment transport in the swash zone with a Boussinesq model coupled with a porous flow model and recognized that the beach grain size significantly affects the ability of the beach to accrete or erode. Hoque and Asano [30] developed a numerical model based on the NLSWE to calculate the wave-induced in/exfiltration flows across the beachface under swash motions and discussed their time-dependent characteristics. Additional description and discussion of the mathematical modeling approaches that have been used to simulate the groundwater flow in the beach and the swash zone were summarized by Horn [32] and Bakhtyar et al. [5]. All the available models that include in/exfiltration from the porous bed are based on simplifying assumptions and do not describe in a detailed way the flow-field in the nearshore zone and the wave motion using the most accurate mathematical description, i.e., the Navier-Stokes (NS) equations.

Bakhtyar et al. [32] developed a two-dimensional (cross-shore) process-based model for the simulation of fluid and sediment characteristics on the impermeable bed in the surf and swash zones. In this model, the hydrodynamic field is described using the ReynoldsAveraged Navier-Stokes (RANS) equations, which is then solved using a Volume-Of-Fluid (VOF) technique and a $k-\varepsilon$ turbulence model. The hydrodynamic model was supplemented by a cross-shore sediment transport and beach profile change model without incorporating the beach groundwater. A sensitivity analysis was conducted to evaluate the importance of model parameters, including the friction factor, porosity and the empirical constants. The aim of the present paper is to further extend the capabilities of the model presented in Bakhtyar et al. [32] to permeable beaches connected to coastal aquifers. Specific objectives of this study are to: (i) validate the new model and evaluate its ability to predict the transport rates and hydrodynamics near the shoreline; (ii) use the validated model to simulate the evolution of the beach groundwater behavior due to high-frequency sea level oscillations; (iii) assess the role of in/exfiltration on sediment transport; and (iv) investigate the relationship between nearshore zone sediment transport and beachface morphology. We remark that although the model below is constructed to account for density-dependent groundwater flow, in this paper we focus on the case of uniform density. The reason for this is that a significant part of what follows concerns the model validation with a laboratory data set for a large-scale experiment using only fresh water. In a subsequent paper, the vali- 
dated model will be used to thoroughly examine the influence of fresh groundwater and denser seawater.

The rest of the paper is organized as follows: Section 2 summarizes the model design, key equations and numerical schemes for dealing with wave breaking and wave runup/down on the beach in the surf and swash zones. It includes beach profile changes and describes groundwater dynamics near the coastline and interactions with the wave motions. Section 3 presents the results of a set of numerical simulations conducted to validate the model against experimental data on a large-scale wave simulator, to investigate how the watertable fluctuates within the beach as a result of wave motion and the evolution of the beachface. Finally, Section 4 summarizes the major findings and conclusions. It should be noted that, for the sake of clarity, in the following the free-water zone is often referred to as 'the sea', as opposed to the groundwater, even though the experimental set-up used for model validation is wave simulator and not the real ocean or sea, as will be clarified in detail in $\S 3.1$.

\section{Model description}

\subsection{Mathematical formulation for modeling wave motion in the nearshore zone}

A combination of a full two-dimensional RANS solver with a $k$ - $\varepsilon$ turbulence closure model and VOF technique for free surface tracking is used to simulate the wave motion near the shoreline. In summary, the key governing equations are (Bakhtyar et al., [33]):

\section{Continuity equation:}

$$
\frac{\partial U_{i}}{\partial x_{i}}=0
$$

Momentum equations:

$$
\frac{\partial U_{i}}{\partial t}+U_{j} \frac{\partial U_{i}}{\partial x_{j}}=g_{i}-\frac{1}{\rho} \frac{\partial P}{\partial x_{i}}+v \frac{\partial^{2} U_{i}}{\partial x_{i}^{2}}+\frac{\partial}{\partial x_{i}}\left(2 v_{t} \frac{\partial U_{i}}{\partial x_{i}}\right)+\frac{\partial}{\partial x_{j}}\left[v_{t}\left(\frac{\partial U_{i}}{\partial x_{j}}+\frac{\partial U_{j}}{\partial x_{i}}\right)\right] \text {, }
$$

Turbulence closure model:

$$
\begin{aligned}
& \frac{\partial k}{\partial t}+U_{i} \frac{\partial k}{\partial x_{i}}=\frac{\partial}{\partial x_{i}}\left[\left(v+\frac{v_{t}}{\sigma_{k}}\right) \frac{\partial k}{\partial x_{i}}\right]+p_{r}-\varepsilon, \\
& \frac{\partial \varepsilon}{\partial t}+U_{j} \frac{\partial \varepsilon}{\partial x_{j}}=\frac{\partial}{\partial x_{j}}\left[\left(v+\frac{v_{t}}{\sigma_{\varepsilon}}\right) \frac{\partial \varepsilon}{\partial x_{j}}\right]+C_{1 \varepsilon} \frac{\varepsilon}{k} P_{r}-C_{2 \varepsilon} \frac{\varepsilon^{2}}{k}, \\
& p_{r}=v_{t}\left[2\left(\frac{\partial U_{i}}{\partial x_{i}}\right)^{2}+\left(\frac{\partial U_{i}}{\partial x_{j}}\right)^{2}\right], \\
& v_{t}=C_{\mu} \frac{k^{2}}{\varepsilon} .
\end{aligned}
$$




$$
\frac{\partial F}{\partial t}+U_{i} \frac{\partial F}{\partial x_{i}}=0
$$

in which $x_{i}=(x, y)$ are the horizontal and vertical coordinates; $U_{i}=(U, V)$ is the mean flow velocity vector; $\rho$ is the mass density of the water; $P$ is the pressure; $k$ is the Turbulent Kinetic Energy (TKE); $v$ is the kinematic viscosity; $v_{t}$ is the kinematic eddy viscosity; $p_{r}$ is the production of TKE due to shear stress; $\varepsilon$ is the TKE dissipation rate; and $F$ is the fluid volume per cell volume. $C_{1 \varepsilon}=1.44, C_{2 \varepsilon}=1.92, \sigma_{k}=1, \sigma_{\varepsilon}=1.3$ and $C_{\mu}=0.09$ are the constants for the $k$ - $\varepsilon$ closure turbulence model (Launder and Spalding, [34]). Note that the summation convention has been assumed.

The initial flow motion was specified with zero mean velocities and hydrostatic pressure, while the initial conditions for the turbulence field were set following Lin [35]. Dynamic and kinematic boundary conditions were considered at the free surface. It was assumed that turbulence does not diffuse across the free surface (Lin, [35]), and so the normal fluxes of $k$ and $\varepsilon$ vanish there. The boundary conditions for $k$ and $\varepsilon$ on the solid surface were specified in a turbulent boundary layer. The local state of turbulence was expressed by use of the log-law and in terms of the mean tangential velocity at a certain distance from the wall (Rodi, [36]). The generating-absorbing boundary condition introduced by Petit et al. [37] was implemented at the entering boundaries for incident wave generation and absorption of reflected waves. The equations were discretized using finite-difference methods based on a staggered grid scheme. Detailed descriptions of mathematical modeling, numerical schemes for discretization of equations, initial and boundary conditions are given by Bakhtyar et al. [32].

\subsection{Groundwater flow}

The aquifer hydrodynamic was computed using the saturated flow model SEAWAT2000 (Guo and Langevin, [38]). SEAWAT-2000 is a USGS computer code that couples MODFLOW-2000 (Harbaugh et al., [39]) for groundwater flow and MT3DMS (Zheng and Wang, [40]) for solute transport. While SEAWAT-2000 is capable of simulate variable-density groundwater flow, as mentioned above in this work this capability was not activated because the erosion experiment used for model validation was conducted using freshwater only. The pressure distribution in the aquifer is computed combining Darcy's law with the mass conservation equation, which for an unconfined homogeneous aquifer with constant water density is:

$S \frac{\partial h}{\partial t}=K \nabla^{2} h-q_{s}$

where $K$ is the hydraulic conductivity; $h$ is the hydraulic head; $S$ is the specific storage coefficient; and $q_{s}$ is the flow rate per unit volume of aquifer for the source or sink. MODFLOW2000, the groundwater flow module of SEAWAT-2000, uses a finite difference cell-centered numerical scheme to solve the groundwater flow equation. We mention that the vertically integrated form of Eq. (8) is solved by MODFLOW-2000. The numerical solutions produced, however, approximate Eq. (8) so long as the model application is based on a sufficient number of layers. 


\subsection{Sediment transport and beach profile changes}

The sediment transport rate is computed using the modified Meyer-Peter and Muller [44] formula including the infiltration and exfiltration effects. In/exfiltration fluxes induce variations in the pressure on the bed surface (lift force), the effective weight, and the normal and shear stress on the bed sediment particles. In this work, we therefore use a modified Shields parameter that incorporates the effects of through-bed flow on the sediment transport (Turner and Masselink, [1]; Butt et al., [26]):

$$
\theta=\frac{\tau\left[\frac{\Phi}{\exp (\Phi)-1}\right]}{\rho g D_{50}(s-1)-\rho g D_{50} \frac{w}{2 K}}, \quad \Phi=\frac{2 w}{f|U|},
$$

where $\theta$ is the Shields parameter, $\tau$ is the bed shear stress, $D_{50}$ and $s$ are the median grain diameter and the specific density of the sediment, respectively, $W$ is the vertical Darcy velocity in the bed $\left(w=-K \frac{\partial \psi}{\partial y}\right), \psi$ is the potential head and $f$ is the friction factor. The numerator in Eq. (9) accounts for the effects of in/exfiltration on the shear stress (increase during the infiltration due to the thinning of the boundary layer and decrease during the exfiltration due to the thickening of the boundary layer), while the denominator incorporates the effects of the water flow across the beachface on the immerged sediment weight (increases during the infiltration leading to stabilization and decreases during the exfiltration causing destabilization). The friction factor is computed as suggested by Butt et al. [26]:

$$
f=\frac{1.28}{\left(\ln \frac{11 h_{s}}{R}\right)^{2}}, \quad R=6 D_{50} \text {, }
$$

where $h_{s}$ is the sea-water depth and $R$ is the Nikuradse effective bed roughness (van Rijn, [45]). As the flow acceleration is an important mechanism in the swash zone sediment transport (Pritchard and Hogg, [46]; Austin et al., [47]), we incorporate the acceleration in the sediment transport formulation by using an additional term that depends on it (Pedrozo-Acuña et al., [48]). Once the sediment transport rate is determined from the above equations, the beach profile change through the conservation of sediment is governed by the following equation:

$$
\frac{\partial Y}{\partial t}=-\frac{1}{(1-n)} \frac{\partial Q}{\partial x},
$$

where $Q$ is the sediment transport rate, $Y$ is the bed level and $n$ is the porosity of the sediment. We used a modified Lax scheme (Abbott, [49]) to solve the Eq. (11) that is the same scheme used by Rakha et al. [50].

\subsection{Coupling procedure}

The coupling between the nearshore zone and the coastal aquifer plays a crucial role in the transfer of mass and pressure across the beachface, which in turn has implications for 
the transport processes at the interface between surface water and groundwater, such as sediment mobility. In this work, we coupled the three processes, namely wave motion, groundwater flow, sediment transport and beach morphology change using the following sequential approach:

(i) Initially, the RANS wave-motion simulator was run to generate the sea surface elevation above the permeable substrate, i.e., beachface and toe, for the entire simulation period.

(ii) The groundwater flow model was run using the sea still water level to obtain groundwater head at the steady state. The nearshore free-water zone (the sea) was approximated as an artificial porous medium with high hydraulic conductivity $\left(10^{6} \mathrm{md}^{-1}\right)$ and unit porosity (the same approach was used for example by Brovelli et al. [20], Robinson et al. [22,51] and Mao et al. [42]). A constant head-type condition was used on both the sea- and land-ward boundaries, although with different elevation, while an impermeable base was assumed at the bottom edge (no-flow boundary condition).

(iii) The same domain and boundary conditions at the bottom and landward edges were used for the subsequent simulation with wave effects included, together with the steady state head distribution as initial conditions. A time-variable head boundary (CHDMODFLOW package) was applied at the sea free surface to mimic the effect of the waves. The water head at each cell along the beach profile was taken from the results of the free-water hydrodynamic simulator. The grid cells drain and re-wet in response to changes in groundwater head (the MODFLOW rewetting capability was activated). The entire simulation length was subdivided into multiple stress-periods, and for each stress period, the initial and final sea elevations (spatially variable in the cross-shore direction) were taken from the wave-motion simulation results. Every stress-period was $0.25 \mathrm{~s}$ long, and was further subdivided into 50 time steps. Within each time step, SEAWAT uses a constant head, computed as a linear interpolation between the initial and final head of the current stress period. SEAWAT-2000 is a saturated flow model, and it considers the porous medium above the watertable (i.e., the capillary fringe and the vadose zone) as inactive. In terms of modeling, this assumption of SEAWAT makes the simulation of the wave runup on the beachface difficult since, for SEAWAT, infiltration would then take place in an inactive zone. Several strategies to overcome this limitation were tested. It was found that the best and most robust approach was to impose the boundary condition directly above the watertable rather than on the beachface. The same approach used successfully by Brovelli et al. [21] to simulate infiltration to the aquifer from the ground surface. When the infiltration is applied directly to the watertable, it should be lagged in time to account for the travel time through the unsaturated zone. In this work, however, since near the runup zone the distance between the saturated zone and the beachface is small and the sand always remains saturated in reality (due to the presence of a capillary fringe), we assumed that the time required for the infiltration is small enough to be ignored (Li et al., [27]). This approximation clearly does not always apply, for example in case of a steep beachface or of a porous medium with low hydraulic conductivity.

(iv) Infiltration and exfiltration fluxes were calculated using the head distribution near the beachface obtained from SEAWAT-2000. Again, since SEAWAT is a saturated-flow model, the fluxes across the beachface above the watertable were computed using the vertical gradient near the watertable and applied to the beach. This is similar to the treatment of the time-variable head boundary condition in (iii) and is justified by the presence of a capillary fringe that connects the watertable and the beachface. The fluxes were used as input for the sediment transport model described in $\S 2.3$, and the evolution of beachface morphology was simulated. 
The models used different, non-overlapping grids, and the grid spacing was selected to guarantee the accuracy of the numerical schemes. For the groundwater simulations a uniform grid with uniform resolution of $0.2 \mathrm{~m}$ was used, whereas the hydrodynamic simulator used a grid with variable spacing, and a resolution locally as low as $0.02 \mathrm{~m}$. The model grids were therefore not overlapping. The hydraulic head applied to the beach surface on the groundwater flow simulator was computed based on linear interpolation of the two nearest grid cells of the hydrodynamic simulator. Since the spacing of both grids is very small, the effect of the interpolation is in practice negligible. Owing to the use of rectangular grids, the beach face was approximated by a 'staircase'. This approximation is likely to result in small errors only, because the beach slope is relatively mild (1:10 slope) and the spatial discretization is fine. At present, there is however no way to evaluate the error introduced by the "staircase" beach. A more refined approach is currently under development, including the use of finite elements to improve the geometrical representation of the domain. Therefore, the effects of this approximation will be tested in future work.

The computational flow chart of the numerical modeling is shown in Fig. 1. The oneway sequential coupling approach used for the model makes use of some simplifying assumptions. First, the nearshore hydrodynamics is not affected by the fluxes across the beachface. This is justified because the pore water flow velocity across the interface of the porous medium is much smaller than the water velocity in the nearshore zone. The second and more critical assumption is that the shape of the beachface is dynamically updated only during the sediment transport calculations. The beach geometry is not modified during the groundwater flow and nearshore simulations, that is, we assume that both direction and magnitude of the fluxes across the interface and the nearshore velocity close to the bed surface are not significantly affected by changes in the beachface morphology. This is not always the case, although it has been previously suggested that the assumption might be valid under certain conditions (Horn et al., [52]). This assumption is likely reasonable when the local slope change induced by erosion/deposition of sediments is small compared to the mean beachface slope. In fact, when the slope change is large, the terms controlling the extent of sediment transport (i.e., shear velocity and magnitude of the vertical flux across the interface) are modified. Dynamic updating of the beachface geometry during the groundwater and nearshore flow modeling would require a two-way tight coupling of the three models (hydrodynamics, groundwater flow, sediment profile change). This would require significant modifications of the structure of the three models, and the resulting simulator would be extremely demanding in terms of CPU time, because the time stepping would always be controlled by the stiffest sub-module. The validation results presented in the following sections illustrate that, at least for the conditions studied here, the two-way coupling is not necessary and the simplifications introduced do not strongly affect model simulations.

\section{Results and Discussion}

Following the model development, numerical simulations were conducted to verify that simulated results correctly reproduced the interactions between beachface, coastal aquifer and high-frequency fluctuations in the nearshore zone and to assess the role and importance of the physical properties of the system (e.g., watertable elevation, hydraulic conductivity, grain size) on the aquifer hydrodynamics and sediment transport. In particular, the extent of in/exfiltration across the beachface, watertable fluctuations, recirculation in the aquifer induced by the waves and beach profile changes in the surf and swash zones were investigated. 


\subsection{Model validation}

The results of the numerical model were compared with the experimental observations reported by Horn et al. [52] and Ang et al. [53]. The data were acquired on a series of experiments conducted in the Coastal Wave Basin of the School of Civil Engineering, University of Queensland, Australia. A sketch of the experimental layout is shown in Fig. 2. The section used in the experiments was 27.3-m long, 1.4-m wide and 0.8-m deep. Two sets of experiments were conducted, using coarse $\left(D_{50}=0.84 \mathrm{~mm}, K=10^{-4} \mathrm{~ms}^{-1}\right)$ or fine $\left(D_{50}=0.197\right.$ $\mathrm{mm}, K=10^{-5} \mathrm{~ms}^{-1}$ ) sand. Within each set, three different groundwater elevations at the landward boundary were used, i.e., higher and lower than, and the same as the Still Water Level (SWL). For the six cases, the water surface elevation above the flat toe (at the seaward boundary) was set to $0.5 \mathrm{~m}$, and a planar initial beach profile (slope of 1:7.6) was used. The landward boundary condition ( $x=0$ in Fig. 2) was provided by a reservoir separated from the rest of the tank via a wire mesh. The water level within the reservoir section was adjusted to maintain the "Initial groundwater elevation" listed in Table 1. This was modeled as a hydrostatic condition. At the other end of the tank, waves were generated using a paddle, and the tank was closed at $x=27.3 \mathrm{~m}$ (Fig. 2). Table 1 summarizes the properties of each of the six cases, where $H$ is the wave height and $T$ is the wave period. Additional details of the experimental setup and discussion of the conditions used during the experiments are provided by Horn et al. [52].

In $§ 3.1 .1$, the focus is on the simulated groundwater level, flow velocities, and head level in the beach aquifer of both coarse and fine sand beaches for different landward groundwater levels. In $\S 3.1 .2$, the simulated beach evolution and foreshore profile changes in the surf and swash zones during wave breaking and wave runup/rundown are presented and discussed.

\subsubsection{Response of beach groundwater to waves}

Variations in the elevation of the watertable indicate that the pressure change induced by the waves on the beachface propagates in the groundwater. An increase in water pressure due to water infiltrating from the nearshore area (for example during wave runup) increases the elevation of the watertable, whereas exfiltration (and the resulting pressure drop) has the opposite effect. The inland propagation of the wave-induced high-frequency pressure signal and its effect on the watertable are controlled by the properties of the porous medium - i.e., hydraulic conductivity and effective porosity in unconfined aquifers and by the capillary effect (Li et al., [6]; Li et al. [54]). In this paper, however, groundwater flow simulations are conducted using a saturated flow model, therefore neglecting capillarity, which in some conditions may affect seepage from the beachface (Li et al., [12]). With the aim of evaluating the importance of the capillary fringe (and possibly other effects that are not included in our simulations) near the beachface, we compared observed and simulated watertable elevations.

Figure 3 illustrates the head for the three landward groundwater table elevations in the fine sand situation (cases $1-3$, Table 1) measured by Horn et al. [52] with the results of the numerical simulations after $10 \mathrm{~min}$. The panels of Fig. 3 show that the simulated changes in groundwater level are in accordance with the measurements for all three fine sand cases with different water levels at the landward boundary (i.e., higher, lower and the same elevation of the SWL). Since the experimental data actually show the heads near the base of the model (a manometer on the bed was used to measure the head), the measured heads can differ from the watertable elevations if significant vertical flow exists. Therefore, in this fig- 
ure, using the numerical model we computed the head both on the bottom and at the free surface. In addition, Table 2 presents the measured data and simulated (at the bed and free surface) heads after $10 \mathrm{~min}$ at different positions. The Root Mean square Error (RMSE) and average value were used to evaluate the model performance. It can be seen that both numerical predictions over-predict the head in all cases. However, the relatively small magnitudes of RMSE and average values indicate that the predictions of the numerical model are reasonable. Note in Fig. 3 and Table 2 that the heads have different magnitudes at the free surface and at the bottom. The maximum differences between numerical and laboratory results occur near the beachface (e.g., $x \sim 1.5 \mathrm{~m}$ ), where the maximum vertical flow exists. The numerical model predicts an increase in watertable elevation near the beachface that is similar to the measured value. The cross-shore head change decreases in the landward direction, because a constant head is used on the landward boundary. We note also that the slopes of the head predictions are reasonably consistent with the experimental data, suggesting that the flow directions predicted by the model are correct. Overall, in the landward area of the beach, excellent agreement between the model predictions and data is found. The differences between the numerical results and experimental data near the beachface may be due to effects of physical processes such as the capillary fringe (not included in the present model), which influences the exchange between seawater and groundwater. However, given the complexity of the processes occurring there, without a more sophisticated modeling approach it is not possible to attribute with any certainty the differences shown in Fig. 3 to the lack of the capillary fringe in the numerical model.

The numerical results (at free surface and bed) and experimental data of head for the coarse sand setup are shown in Fig. 4. The three panels illustrate the results for the different watertable elevations set at the inland boundary. Table 3 gives the measured and simulated heads at different positions. Figure 4 and Table 3 confirm that the numerical model can efficiently simulate the wave-groundwater interactions and gives similar trends in head level variations, as for the fine sand case. Despite the neglect of the unsaturated zone, the interactions between free- and groundwater and the watertable dynamics within and near the swash zone are reasonably well reproduced. While near the beachface the simulations are compatible with the observations in all cases, landward the computed heads do not completely reproduce the measurements for case 6 (with coarse sand and landward head elevation higher than the SWL). In addition, the experimental data for case 6 seem problematic near the landward limit. The vertical flow component near the $x=0$ boundary would be negligible if flow into the tank came from a hydrostatic reservoir, the height of which was set to $0.55 \mathrm{~m}$ in the experiment. Figure 4c shows also that the gradient of the measured data and the simulations are in the opposite directions. We are unable to be definitive about the differences shown in Fig. 4c. One possibility is that the reservoir condition is not hydrostatic, rather there is a circulation within this zone that induces a pronounced flow near the base of the tank, resulting in the head gradient shown in the figure. Without measurements of the head profile within the reservoir, it is not possible to do other than speculate why Case 6 in Fig. 4 shows discrepancies. Another possible explanation for this inconsistency might be related to the neglect of the capillary fringe, since it was shown that one of its effects is to weaken damping of the waves (Li et al., [12]). More precisely, in the model inland propagation of the watertable fluctuations induced by waves is more limited than in the experiments because the recharge due to water released from the capillary fringe is neglected. Furthermore, vertical flow effects can be important here because the data are heads measured at the base of the model, not direct measurements of the watertable elevations. 
A comparison of Figs. 3 and 4 demonstrates that in the aquifer the head change in the fine sand beach is generally slightly smaller than that in the coarse sand. This is consistent with previous results, and is due to the different hydraulic properties. In- and exfiltration rates depend on hydraulic conductivity. Increasing the hydraulic conductivity leads to an increase in the groundwater response to the wave motion. In all watertable elevations, the difference of head level between coarse and fine sands decrease towards the sea. Furthermore, the maximum difference in head levels (between experiments and numerical results) occurs when the groundwater level is the lower than the SWL (excluding case 6 that seems a problematic as discussed above). Figure 5 illustrates the time variation of the head at the location where the sea SWL crosses the beachface at different depths. Results are shown for both fine and coarse sands and for (a) the same watertable and SWL, (b) lower watertable, and (c) higher watertable elevations. It is evident that the head increased with the watertable elevation, and that it fluctuated with the same period as the waves. From Fig. 3, it can be seen that the largest difference between the numerical results and the experimental data occurs near the intersection of the SWL and the beachface (between $x=1$ to $1.5 \mathrm{~m}$ ). The results in Fig. 5 suggest another possible explanation for the observed discrepancies. In the experiments, a manometer on the bed of the flume was used to measure the local head, which might provide an estimate of the watertable elevation if vertical flow was negligible (Horn et al., [52]). Note that the manometer would have filtered high-frequency oscillations and measured the average head. The determination of the watertable using the head data was based on the assumption of a hydrostatic head at each measurement location. Figure 3 shows that the model-predicted free surface and that deduced from the experimental data typically differ most where the vertical flux calculated by the model is greatest.

Time-averaged (over 15min) groundwater heads in the aquifer for the six cases are shown in Figs. 6 and 7. Wave motion on the beach induces groundwater head oscillations near the shore. More importantly, wave set-up and set-down (time-averaged effects manifested as on-shore and off-shore tilting of the averaged sea level) induce pore water circulations inside the beach. The time-averaged groundwater heads display the locations where most of the periodic groundwater circulation occurs below progressive waves and within the porous media, which are important for understanding the solute exchange between groundwater and sea, as pointed out by $\mathrm{Li}$ et al. [55]. The average head shows variations over depth below the beachface, and therefore that the Boussinesq approximation of uniform heads in the vertical direction is unlikely to be a useful approximation. In addition, Figs. 6 and 7 show that the lower landward watertable gives the largest area of red (high average head) in the plot. This is because the head on the landward boundary is fixed, and the head on the beachface is controlled by the waves, which are independent of the watertable elevation. Therefore, in the lower watertable case, the wave signal (head change) can propagate much more into the aquifer because it is less counterbalanced by the fixed head at the landward boundary.

Wave setup on the beachface induces in/exfiltration across the beach. In order to examine further the behavior and magnitude of the interactions between ocean and groundwater, the rate of mass exchange (in- and exfiltration) was calculated. Averaged in/exfiltration rates on the beachface on the fine sand beach for the three cases with different inland watertable levels are shown in Fig. 8. As the wave propagates along the slope, due to shoaling effects the wave breaks at approximately $x=2.5 \mathrm{~m}$. The broken wave then propagates towards the shore, and runs up and down on the beach. The simulated flux across the beachface shows that the maximum infiltration takes place at the upper part of the beach $(x=1.5 \mathrm{~m})$, while exfiltration is the largest near the breaking point $(x=2.5 \mathrm{~m})$. In the vicinity of where the wave breaks, a strong hydraulic gradient exists, and net infiltra- 
tion occurs across the beachface before the breaking point, while exfiltration takes place below the breaking point. These findings are essentially consistent with existing understanding of the wave-induced beach groundwater flow in the nearshore zone (Li and Barry, [8]). Our results therefore further suggest that the location of wave breaking and the magnitude of the resulting hydraulic gradient are important features for the sediment transport and foreshore evolution processes. A comparison of the three panels of Fig. 8 illustrates that not surprisingly - the maximum infiltration occurs for low groundwater level conditions (i.e., panel (b)). In terms of consequences for sediment transport this indicates that the low groundwater level is the most favorable for sediment deposition and therefore for beach accretion. This result suggests that low groundwater levels promote the infiltration of solutes from the sea, and for example recharge the groundwater with oxygen, thus enhancing oxidative biological processes. In addition, Fig. 8 shows the in/exfiltration flux as it varies with cross-shore distance, where it is apparent that the maximum values coincide with the maximum differences between numerical predictions and data shown in Fig. 3.

Figure 9 displays the averaged cross-shore in/exfiltration rates on the beachface for the coarse sand beach in the surf and swash zones. A comparison of Figs. 8 and 9 shows that, due to the larger hydraulic conductivity, the infiltration and exfiltration on the coarse sand beach are larger than the corresponding values on the fine sand beach. This indicates that sediment transport in a coarser beach may be more sensitive to the fluxes across the beachface.

In order to examine further the behavior of the wave-induced groundwater circulation, the direction and magnitude of the Darcy flux was computed using the time-averaged head distribution in the sand. Figures 10 and 11 depict the averaged flow velocity field for fine and coarse sand beaches, respectively (note that the length of the arrows is proportional to the velocity magnitude). It should be noted that the set-up used here might not be fully representative of real conditions in that an impermeable boundary is located just below the sloping beach.

For the conditions studied here, similar circulation patterns are observed regardless the hydraulic conductivity of the sand and the level of the groundwater, and four circulation cells form beneath the beach. Near the wave breaking point (at a distance of about $2.5 \mathrm{~m}$ from the landward boundary) the flow field converges. Water infiltrates seaward due to the wave-induced hydraulic gradient (set-down) on the beachface (at about $x=3.25 \mathrm{~m}$ ) and is then discharged back to the ocean near the breaking point. The water that infiltrates from the swash zone is also partly discharged in the vicinity of the breaking point, thus creating two convective cells below the beachface. Although the magnitude of the fluxes changes significantly depending on the elevation of the watertable and hydraulic conductivity, the circulation patterns persists. This has important consequences in terms of solute transport, and potentially is one of the key mechanisms for submarine groundwater discharge. Near the maximum location reached during wave runup the flow field is divergent. Part of the water moves seaward and is discharged at the wave breaking point, as already discussed. The remainder moves instead landward, and mixes with the ambient groundwater. Compared to the same-elevation case, in low watertable conditions the circulation cell and position of the diverging flow are shifted seaward, whereas for higher watertable the opposite behavior is observed. Moreover, panel (b) shows that the lower watertable increases the infiltration and decreases the exfiltration, while panel (c) further confirms that the higher watertable increases the exfiltration and decreases the infiltration. 


\section{2 Foreshore profile evolution during the wave motion for different groundwater levels}

In this section, the hydrodynamic and groundwater flow models are supplemented with a sediment transport formula and sediment continuity equation to calculate foreshore profile changes in the surf and swash zones for the different types and characteristics of beach and groundwater flow.

Figure 12 illustrates the predicted and measured foreshore profile changes for the fine sand beaches. The three panels correspond to the three landward groundwater levels: (a) same as the SWL, (b) lower and (c) higher than the SWL. Model results exhibit similar erosion and deposition patterns on the beachface to those observed in the experiments.

Both the simulated and measured profiles in panels $(a, c)$ show that erosion takes place above the interaction of SWL with beachface and the sediment accumulate landward with the buildup of a sand bar below the SWL. In other words, on the fine sand beach, the condition is erosive and sediment transport in the off-shore direction is dominant. Moreover, a comparison between the three panels shows that when the groundwater level is lower than the SWL (panel b), sediment transport occurs in both on-shore (at the upper part of beachface) and off-shore (at mid and lower part of beach) directions, leading to a transitional beach profile.

A comparison between the measured and simulated beach profiles on the coarse sand beach for different groundwater elevations in the nearshore zone are presented in Fig. 13. The results of foreshore profile changes show the erosion below the SWL and development of a berm above the SWL. Moreover, most of the erosion occurs near the wave breaking point since wave breaking enhances TKE, momentum exchange between the sediment and fluid phases, interaction between the grains and hence sediment transport in the form of erosion.

Figure 14 shows the foreshore profile evolution on the fine and coarse sand beaches without groundwater effects. A comparison of beach profile for fine and coarse beaches reveals that the morphodynamic condition changes completely from erosive (for fine sands) to accretionary (for coarse sand). It is found that the sediment transport flux is offshoreward for finer particles and on-shoreward for coarser particles. These results are in general agreement with previous observation and simulations [Turner and Masselink, [1]; Hoque and Asano [30]). Hoque and Asano [30] provided a physical explanation of the onshore and off-shore sediment transport for coarse and fine particles, stating that "the effective weight effect is predominant for finer particles causing net offshore transport, whereas the boundary layer modification effect is predominant for coarser particles causing net onshore transport". Throughout the field measurements, Turner and Masselink [1] found that when $D_{50}<0.5 \mathrm{~mm}$ (similar to cases 1-3), effective weight effect is predominant; changing to boundary layer modification effects for $D_{50}>0.5 \mathrm{~mm}$ (like cases 4-6). An important fact underpinning these two effects is the hydraulic conductivity of the sediment. For coarser sands, the hydraulic conductivity is larger, leading to higher in/exfiltration rates.

In addition, the results in Fig. 14 lead to the conclusion that off-shoreward transport of fine sand and on-shoreward transport of coarse sand can be attributed to the change in settling velocities. Fine sands that are picked up during on-shore wave motion do not have time to return to the beachface. During the subsequent off-shore flow, the fine sands in the water column are transported to and deposited in the off-shore area (Ribberink et al., [56]). We can estimate from the numerical results the potential response time of a particle to set- 
tle down due to gravity by comparing the settling time scale (water depth per settling velocity) with the period of the incident waves. Assuming that the settling velocity is described by Stokes Law then, for fine sand, the settling time scale was found to be greater than wave period. For coarse sand the settling time scale is shorter than wave period. This implies that sediment deposition over the time scale of a wave period is mainly controlled by gravity.

In both coarse and fine beaches, the largest berm above SWL develops when the groundwater level is lower than the SWL. This is due to the higher infiltration rates (see Figs. $8 \mathrm{~b}$ and $9 \mathrm{~b}$ ) that made infiltration-induced stability the dominant effect. These results provide evidence for the hypothesis that infiltration increases on-shore sediment transport and promotes growth of the beach.

A comparison of beach profile changes for coarse and fine sands shows that the erosion below the SWL and the berm formed above the SWL are greater on the coarse beach than on the fine beach. Correspondingly, the beachface gradient of coarse sand is greater than that of the fine sand beach, a result that is consistent with previous findings (Masselink and Li. [25]).

In summary, the numerical model has been demonstrated to capable of simulating the characteristics of the sediment transport and profile variations in the nearshore zone as observed the laboratory experiments. Simulations and experimental data show that the beach groundwater table elevation influences both the sediment transport and the foreshore profile in almost all conditions. However, a more significant role for the profile changes is played by the fluxes across the beachface, i.e., in- and exfiltration, on coarse sandy beaches.

\section{Summary and Conclusions}

Most existing numerical models of beach groundwater motion are related to the tidal forces. In this study, interactions between fresh groundwater and denser seawater, salt transport and wave motion were investigated using a newly developed process-based model. The nearshore hydrodynamics were computed using the NS equations in conjunction with a $k-\varepsilon$ closure turbulence model and the VOF technique. The bed deformation was calculated using an empirical sediment transport formula that accounts for the influence of the fluxes across the beachface, coupled to the continuity equation for the sediments. Aquifer hydrodynamics and the interactions between the ambient groundwater and the coastal waves were modeled using SEAWAT-2000, a groundwater flow model. Wave-induced watertable fluctuations and the effects of in/exfiltration on the nearshore sediment transport were analyzed and discussed. Results obtained from the numerical simulations were compared to published experimental data, showing good agreement for different watertable elevations and properties of the porous medium. Based on the simulation results, the following conclusions can be drawn:

- The wave motion is well described by the hydrodynamic model, and the beach groundwater flow can be simulated well using the groundwater flow model. In addition, the interaction between the wave propagation and aquifer is reproduced, although the predictions are not always fully satisfactory.

- In the swash zone, the maximum infiltration rate occurs on the upper part of beach, while in the surf zone, due to a great gradient in the hydraulic head, infiltration occurred across the beachface before the breaking point and exfiltration took place below the breaking point. 
- The watertable fluctuations (head change) were more profound on the coarse than on the fine sand.

- The results of foreshore profile changes for coarse sand beach show erosion below the SWL and development of a berm above the SWL. Moreover, the largest erosion was observed near the wave breaking point. In contrast, the simulated and measured profiles of the fine sand beach show erosion above the SWL with the generation of a bar below the SWL. In other words, for fine sand, the dominant direction for sediment transport is towards the off-shore and on the coarse sand beach it is on-shore.

- In both coarse and fine beaches, the largest berm develops above the SWL when the groundwater level is low. In this condition, the infiltration is higher and infiltrationinduced stability plays an important role in shaping the beach profile. Therefore, infiltration increased on-shore sediment transport and beach accretion.

- A comparison of beach profile changes for coarse and fine sands showed that (i) the erosion below the SWL and (ii) the formation of the berm above the SWL is greater on the coarse beach than on the fine beach. In addition, the beachface gradient for coarse sand is greater than that of the fine sand beach.

- Even though beach aquifer influences the sediment transport and foreshore profile variations in nearly every condition, in/exfiltration plays a stronger role on the profile change for the coarse sand than for fine sand beaches, due to the different hydraulic properties.

- Many mathematical and analytical models that simulate groundwater flow in coastal aquifers are based on hydrostatic conditions (i.e., they assume the vertical flow is negligible relative to the horizontal flow). The numerical results of this study, which assumed a steep beach, reveal that the hydrostatic assumption is likely reasonable at least in the present case of no density variations and considering phase-averaged flow.

The model's capability to predict sediment transport and groundwater hydrodynamics under ocean/aquifer interactions underscores its potential for understanding the evolution of beach morphology (e.g., to predict in which conditions there will be erosion, to design dewatering schemes, etc.). To investigate the groundwater hydrodynamics in a more realistic set-up (field scale conditions, variable-density groundwater flow, etc.) and subjected to the influence of waves, additional work is needed. Numerical experiments to analyze the sensitivity of sediment transport and predict how different beach configurations are affected by the physical processes in coastal aquifers are part of an ongoing study.

\section{Acknowledgement}

Support of the Swiss National Foundation (SNF 200021_124780) is acknowledged.

\section{References}

[1] Turner IL, Masselink G. Swash infiltration-exfiltration and sediment transport. J Geophys Res 1998;103:30813-25.

[2] Li L, Barry DA, Pattiaratchi CB. Modeling coastal groundwater response to beach dewatering. J Waterway Port Coast Ocean Eng ASCE 1996;122:273-80. 
[3] Horn D, Li L. Measurement and modeling of gravel beach groundwater response to wave run-up: Effects on beach profile changes. J Coast Res 2006;22:1241-49.

[4] Elfrink B, Baldock TE. Hydrodynamics and sediment transport in the swash zone: A review and perspectives. Coast Eng 2002;45:149-67.

[5] Bakhtyar R, Barry DA, Li L, Jeng DS, Yeganeh-Bakhtiary A. Modeling sediment transport in the swash zone: A review. Ocean Eng 2009;36:767-83.

[6] Li L, Barry DA, Pattiaratchi CB, Masselink G. BeachWin: Modeling groundwater effects on swash sediment transport and beach profile changes. Env Model Softw 2002;17:313-20.

[7] Hensley PJ, Barry DA. On describing fluid flow in porous media. Geotech Eng 1993;23:131-43.

[8] Li L, Barry DA. Wave-induced beach groundwater flow. Adv Water Resour 2000;23:325-37.

[9] Li L, Barry DA, Jeng D-S, Prommer H. Tidal dynamics of groundwater flow and contaminant transport in coastal aquifers, In Coastal Aquifer Management-Monitoring, Modeling, and Case Studies, A. H.-D. Cheng and D. Ouazar (editors), Chapter 6, Lewis Publishers, Boca Raton, Florida; 2004, p. 115-41.

[10] Nielsen P. Tidal dynamics of the water table in beaches. Water Resour Res 1990;26:2127-34.

[11] Baird AJ, Horn DP. Monitoring and modeling ground water behavior in sandy beaches. J Coast Res 1996;12:630-40.

[12] Li L, Barry DA, Pattiaratchi CB. Numerical modeling of tide-induced beach water table fluctuations. Coast Eng 1997;30:105-23.

[13] GuoQ, Li H, Boufadel MC, Xia Y, Li G. Tide-induced groundwater head fluctuation in coastal multi-layered aquifer systems with a submarine outlet-capping. Adv Water Resour 2007;30:1746-55.

[14] Barry DA, Barry SJ, Parlange J-Y. Capillarity correction to periodic solutions of the shallow flow approximation, In Mixing Processes in Estuaries and Coastal Seas, C. B. Pattiaratchi (editor), Coastal and Estuarine Studies, Volume 50, American Geophysical Union, Washington, DC, 1996, p. 496-510.

[15] Parlange J-Y, Stagnitti F, Starr JL, Braddock RD. Free-surface flow in porous media and periodic solution of the shallow-flow approximation. J Hydrol 1984;70:251-63.

[16] Destouni G, Prieto C. On the possibility for generic modelling of submarine groundwater discharge. Biogeochemistry 2003;66:171-86.

[17] Smith AJ. Mixed convection and density-dependent seawater circulation in coastal aquifers. Water Resour Res 2004;40, W08309, doi:10.1029/2003WR002977.

[18] Vandenbohede A, Lebbe L. Occurrence of salt water above fresh water in dynamic equilibrium in a coastal groundwater flow system near De Panne, Belgium. Hydrogeol J 2005;doi:10.1007/s10040-0050446-5.

[19] Mao X, Enot P, Barry DA, Li L, Binley A, Jeng D-S. Tidal influence on behaviour of a coastal aquifer adjacent to a low-relief estuary. J Hydrol 2006;327:110-27.

[20] Robinson C, Gibbes B, Li L. Driving mechanisms for flow and salt transport in a subterranean estuary. Geophys Res Lett 2006;33, L03402, doi:10.1029/2005GL025247.

[21] Brovelli A, Mao X, Barry DA. Numerical modeling of tidal influence on density-dependent contaminant transport. Water Resour Res 2007;43,W10426, doi:10.1029/2006WR005173.

[22] Robinson C, Li L, Barry DA. Effect of tidal forcing on a subterranean estuary. Adv Water Resour 2007;30:851-65. 
[23] Kobayashi N, Wurjanto A. Numerical model for waves on rough permeable slopes. J Coast Res, Special Issue No. 7 on Rational Design of Mound Structures 1990:149-66.

[24] Cartwright N, Nielsen P, Li L. Experimental observations of watertable waves in an unconfined aquifer with a sloping boundary. Adv Water Resour 2004;27:991-1004.

[25] Masselink G, Li L. The role of swash infiltration in determining the beachface gradient: A numerical study. Mar Geol 2001;176:139-56.

[26] Butt T, Russell P, Turner I. The influence of swash infiltration-exfiltration on beach face sediment transport: Onshore or offshore? Coast Eng 2001;42:35-52.

[27] Li L, Barry DA, Parlange J-Y, Pattiaratchi CB. Beach water table fluctuations due to wave run-up: Capillarity effects. Water Resour Res 1997;33:935-45.

[28] Karambas TV. Modelling infiltration-exfiltration effects on cross-shore sediment transport in the swash zone. Coast Eng J 2003;45:63-82.

[29] Karambas TV. Prediction of sediment transport in the swash zone by using a nonlinear wave model. Cont Shelf Res 2006;26:599-609.

[30] Hoque Md, Asano T. Numerical study on wave-induced filtration flow across the beach face and its effects on swash zone sediment transport. Ocean Eng 2007;34:2033-44.

[31] Horn DP. Measurements and modeling of beach groundwater flow in the swash-zone: A review. Cont Shelf Res 2006;26:622-52.

[32] Bakhtyar R, Ghaheri A, Yeganeh-Bakhtiary A, Barry DA. Process-based model for nearshore hydrodynamics, sediment transport and morphological evolution in the surf and swash zones. Applied Ocean Res 2009;31:44-56.

[33] Bakhtyar R, Barry DA, Yeganeh-Bakhtiary A, Ghaheri A. Numerical simulation of surf-swash zone motions and turbulent flow. Adv Water Resour 2009;32:250-63.

[34] Launder BE, Spalding DB. The numerical computation of turbulent flows. Com Meth Applied Mech Eng 1974;3:269-89.

[35] Lin P. Numerical modeling of breaking waves, PhD Dissertation, Cornell University, Ithaca, NY, 1998.

[36] Rodi W. Turbulence models and their application in hydraulics, a state of the art review. Delft, the Netherlands: IAHR publication; 1980.

[37] Petit HAH, Tonjes P, van Gent MRA, van den Bosch P. Numerical simulation and validation of plunging breakers using a 2D Navier-Stokes model. In: Proceedings of $24^{\text {th }}$ Conference on Coastal Engineering, ASCE; 1995, p. 511-24.

[38] Guo W, Langevin CD. User's guide to SEAWAT: A computer program for simulations of three-dimensional variable density groundwater flow, US Geological Survey Techniques of Water-Resources Investigations 6-A7, Tallahassee, Florida; 2002.

[39] Harbaugh AW, Banta ER, Hill MC, McDonald MG. MODFLOW-2000, The US Geological Survey modular ground-water model-user guide to modularization concepts and the groundwater flow process, US Geological Survey Open File Report 00-92; 2000.

[40] Zheng C, Wang MC. MT3DMS-A modular three-dimensional multispecies transport model for simulation of advection, dispersion and chemical reactions of contaminant in groundwater systems; documentation and user's guide. US Army Corps of Engineers Contract Report SERDP-99-1; 1999.

[41] Barry DA. Supercomputers and their use in modeling subsurface solute transport. Rev Geophys 1990;28:277-95. 
[42] Mao X, Prommer H, Barry DA, Langevin CD, Panteleit B, Li L. Three-dimensional model for multicomponent reactive transport with variable density groundwater flow. Env Model Softw 2006;21:61528. Doi: 10.1016/j.envsoft.2004.11.008.

[43] Robinson C, Li L, Prommer H. Tide-induced recirculation across the aquifer-ocean interface. Water Resour Res 2007;43, W07428, doi:10.1029/2006WR005679.

[44] Meyer-Peter E, Muller R. Formulas for bed-load transport. In: Proceedings $3^{\text {rd }}$ Meeting of the International Association for Hydraulic Research, Stockholm, Sweden; 1948, p. 39-64.

[45] van Rijn LC. Principles of Sediment Transport in Rivers, Estuaries and Coastal Seas. Aqua Publications, The Netherlands, 584 pp; 1993.

[46] Pritchard D, Hogg AJ. On the transport of suspended sediment by a swash event on a plane beach. Coast Eng 2005;52:1-23.

[47] Austin M, Masselink G, O’Hare T, Russell P. Onshore sediment transport on a sandy beach under varied wave conditions: Flow velocity skewness, wave asymmetry or bed ventilation? Mar Geol 2009;259:86101.

[48] Pedrozo-Acuña A, Simmonds DJ, Chadwick AJ, Silva R. A numerical-empirical approach for evaluating morphodynamic processes on gravel and mixed sand-gravel beaches. Mare Geol 2007;241:1-18.

[49] Abbott MB. Computational Hydraulics. Pitman Books. London, 1979.

[50] Rakha KA, Deigaard R, Brøker I. A phase-resolving cross-shore sediment transport model for beach profile evolution. Coast Eng 1997;31:231-61.

[51] Robinson C, Brovelli A, Barry DA, Li L. Tidal influence on BTEX biodegradation in sandy coastal aquifers. Adv Water Resour 2009;32:16-28.

[52] Horn DP, Baldock TE, Li L. The influence of groundwater on profile evolution of fine and coarse sand beaches. In: Proceedings of Coastal Sediments ‘07, New Orleans, ASCE; 2007, p. 506-19.

[53] Ang LS, Sum CH-Y, Baldock TE, Li L, Nielsen P. Measurement and Modelling of Controlled Beach Groundwater Levels Under Wave Action. In 15 th Australasian Fluid Mechanics Conference, The University of Sydney, Sydney, Australia, 13-17 December 2004.

[54] Li L, Barry DA, Stagnitti F, Parlange J-Y. Groundwater waves in a coastal aquifer: A new governing equation including vertical effects and capillarity. Water Resour Res 2000;36:411-20.

[55] Li L, Barry DA, Stagnitti F, Parlange J-Y. Submarine groundwater discharge and associated chemical input to a coastal sea. Water Resour Res 1999;35:3253-59.

[56] Ribberink JS, Van der Werf JJ, O’Donoghue T, Hassan WNM. Sand motion induced by oscillatory flows: sheet flow and vortex ripples. J Turbul 2008;9:1-32. 
Table 1. Characteristics of the waves and groundwater conditions in the experiments reported by Horn et al. [52] and Ang et al. [53].

\begin{tabular}{cccccc}
\hline Case & $H(\mathrm{~m})$ & $K_{f}\left(\mathrm{~ms}^{-1}\right)$ & $D_{50}(\mathrm{~mm})$ & $T(\mathrm{~s})$ & $\begin{array}{c}\text { Initial ground- } \\
\text { water elevation } \\
(\mathrm{m})\end{array}$ \\
\hline 1 & 0.15 & $10^{-5}$ & 0.197 & 2.5 & 0.5 \\
2 & 0.15 & $10^{-5}$ & 0.197 & 2.5 & 0.45 \\
3 & 0.15 & $10^{-5}$ & 0.197 & 2.5 & 0.55 \\
4 & 0.15 & $10^{-4}$ & 0.84 & 2.5 & 0.5 \\
5 & & & & & 0.45 \\
& 0.15 & $10^{-4}$ & 0.84 & 2.5 & 0.55 \\
\hline
\end{tabular}


Table 2. Pressure head in the coastal aquifer for fine sand after $10 \mathrm{~min}$ at different positions.

\begin{tabular}{|c|c|c|c|c|}
\hline Case & $\begin{array}{l}\text { Cross-shore } \\
\text { distance (m) }\end{array}$ & $\begin{array}{l}\text { Experimental Meas- } \\
\text { urement }(\mathrm{m})\end{array}$ & $\begin{array}{l}\text { Numerical simula- } \\
\text { tion at bottom (m) }\end{array}$ & $\begin{array}{l}\text { Numerical simula- } \\
\text { tion at free surface } \\
(\mathrm{m})\end{array}$ \\
\hline \multirow{11}{*}{$\begin{array}{l}\text { Fine sand-lower } \\
\text { watertable level }\end{array}$} & 0.20 & 0.45 & 0.460 & 0.474 \\
\hline & 0.35 & 0.46 & 0.486 & 0.469 \\
\hline & 0.50 & 0.51 & 0.498 & 0.486 \\
\hline & 0.65 & 0.51 & 0.512 & 0.500 \\
\hline & 0.80 & 0.51 & 0.525 & 0.515 \\
\hline & 0.95 & 0.51 & 0.537 & 0.530 \\
\hline & 1.10 & 0.51 & 0.548 & 0.546 \\
\hline & 1.25 & 0.51 & 0.557 & 0.567 \\
\hline & 1.50 & 0.51 & 0.561 & 0.575 \\
\hline & Average & 0.50 & 0.521 & 0.518 \\
\hline & RMSE & - & 0.030 & 0.034 \\
\hline \multirow{11}{*}{$\begin{array}{l}\text { Fine sand-same } \\
\text { watertable level }\end{array}$} & 0.20 & 0.50 & 0.509 & 0.509 \\
\hline & 0.35 & 0.50 & 0.517 & 0.517 \\
\hline & 0.50 & 0.52 & 0.525 & 0.524 \\
\hline & 0.65 & 0.52 & 0.533 & 0.532 \\
\hline & 0.80 & 0.52 & 0.542 & 0.540 \\
\hline & 0.95 & 0.53 & 0.550 & 0.548 \\
\hline & 1.10 & 0.53 & 0.557 & 0.557 \\
\hline & 1.25 & 0.52 & 0.561 & 0.570 \\
\hline & 1.50 & 0.52 & 0.562 & 0.572 \\
\hline & Average & 0.52 & 0.539 & 0.541 \\
\hline & RMSE & - & 0.025 & 0.029 \\
\hline \multirow{11}{*}{$\begin{array}{c}\text { Fine sand-Higher } \\
\text { watertable level }\end{array}$} & 0.20 & 0.55 & 0.549 & 0.551 \\
\hline & 0.35 & 0.55 & 0.553 & 0.550 \\
\hline & 0.50 & 0.56 & 0.556 & 0.553 \\
\hline & 0.65 & 0.56 & 0.558 & 0.557 \\
\hline & 0.80 & 0.55 & 0.561 & 0.561 \\
\hline & 0.95 & 0.55 & 0.564 & 0.566 \\
\hline & 1.10 & 0.55 & 0.567 & 0.571 \\
\hline & 1.25 & 0.55 & 0.567 & 0.578 \\
\hline & 1.50 & 0.54 & 0.563 & 0.569 \\
\hline & Average & 0.55 & 0.560 & 0.562 \\
\hline & RMSE & - & 0.013 & 0.017 \\
\hline
\end{tabular}


Table 3. Pressure head in the coastal aquifer for coarse sand after $10 \mathrm{~min}$ at different positions.

\begin{tabular}{|c|c|c|c|c|}
\hline Case & $\begin{array}{l}\text { Cross-shore } \\
\text { distance }(\mathrm{m})\end{array}$ & $\begin{array}{l}\text { Experimental Meas- } \\
\text { urement }(\mathrm{m})\end{array}$ & $\begin{array}{l}\text { Numerical simula- } \\
\text { tion at bottom (m) }\end{array}$ & $\begin{array}{l}\text { Numerical simula- } \\
\text { tion at free surface } \\
(\mathrm{m})\end{array}$ \\
\hline \multirow{11}{*}{$\begin{array}{l}\text { Fine sand-lower } \\
\text { watertable level }\end{array}$} & 0.20 & 0.48 & 0.466 & 0.476 \\
\hline & 0.35 & 0.51 & 0.489 & 0.479 \\
\hline & 0.50 & 0.54 & 0.502 & 0.491 \\
\hline & 0.65 & 0.54 & 0.514 & 0.504 \\
\hline & 0.80 & 0.55 & 0.527 & 0.517 \\
\hline & 0.95 & 0.56 & 0.538 & 0.532 \\
\hline & 1.10 & 0.56 & 0.549 & 0.547 \\
\hline & 1.25 & 0.56 & 0.556 & 0.566 \\
\hline & 1.50 & 0.54 & 0.559 & 0.572 \\
\hline & Average & 0.54 & 0.523 & 0.521 \\
\hline & RMSE & - & 0.021 & 0.029 \\
\hline \multirow{11}{*}{$\begin{array}{l}\text { Fine sand-same } \\
\text { watertable level }\end{array}$} & 0.20 & 0.54 & 0.509 & 0.514 \\
\hline & 0.35 & 0.55 & 0.523 & 0.517 \\
\hline & 0.50 & 0.56 & 0.531 & 0.524 \\
\hline & 0.65 & 0.56 & 0.539 & 0.532 \\
\hline & 0.80 & 0.57 & 0.547 & 0.539 \\
\hline & 0.95 & 0.58 & 0.554 & 0.548 \\
\hline & 1.10 & 0.57 & 0.561 & 0.557 \\
\hline & 1.25 & 0.56 & 0.565 & 0.571 \\
\hline & 1.50 & 0.55 & 0.563 & 0.573 \\
\hline & Average & 0.56 & 0.544 & 0.542 \\
\hline & RMSE & - & 0.022 & 0.026 \\
\hline \multirow{11}{*}{$\begin{array}{l}\text { Fine sand-Higher } \\
\text { watertable level }\end{array}$} & 0.20 & 0.65 & 0.553 & 0.553 \\
\hline & 0.35 & 0.64 & 0.555 & 0.555 \\
\hline & 0.50 & 0.64 & 0.558 & 0.558 \\
\hline & 0.65 & 0.63 & 0.561 & 0.561 \\
\hline & 0.80 & 0.62 & 0.563 & 0.564 \\
\hline & 0.95 & 0.61 & 0.566 & 0.567 \\
\hline & 1.10 & 0.60 & 0.567 & 0.572 \\
\hline & 1.25 & 0.58 & 0.567 & 0.579 \\
\hline & 1.50 & 0.55 & 0.561 & 0.569 \\
\hline & Average & 0.61 & 0.5616 & 0.5646 \\
\hline & RMSE & - & 0.062 & 0.061 \\
\hline
\end{tabular}




\section{Coupled ocean-groundwater model}

\begin{tabular}{|c|c|c|c|}
\hline $\begin{array}{c}\text { Hydrodynamic } \\
\text { model }\end{array}$ \\
$\begin{array}{c}\text { Turbulence, wave } \\
\text { velocities, water } \\
\text { surface elevation }\end{array}$
\end{tabular}

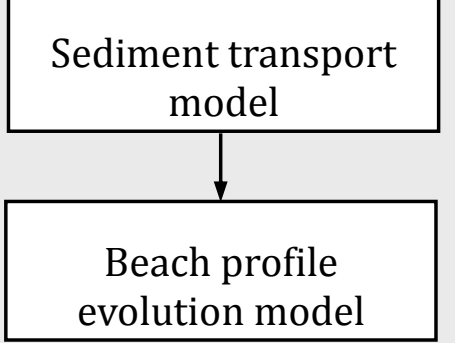

Fig. 1. Computational flow chart of the numerical model. 


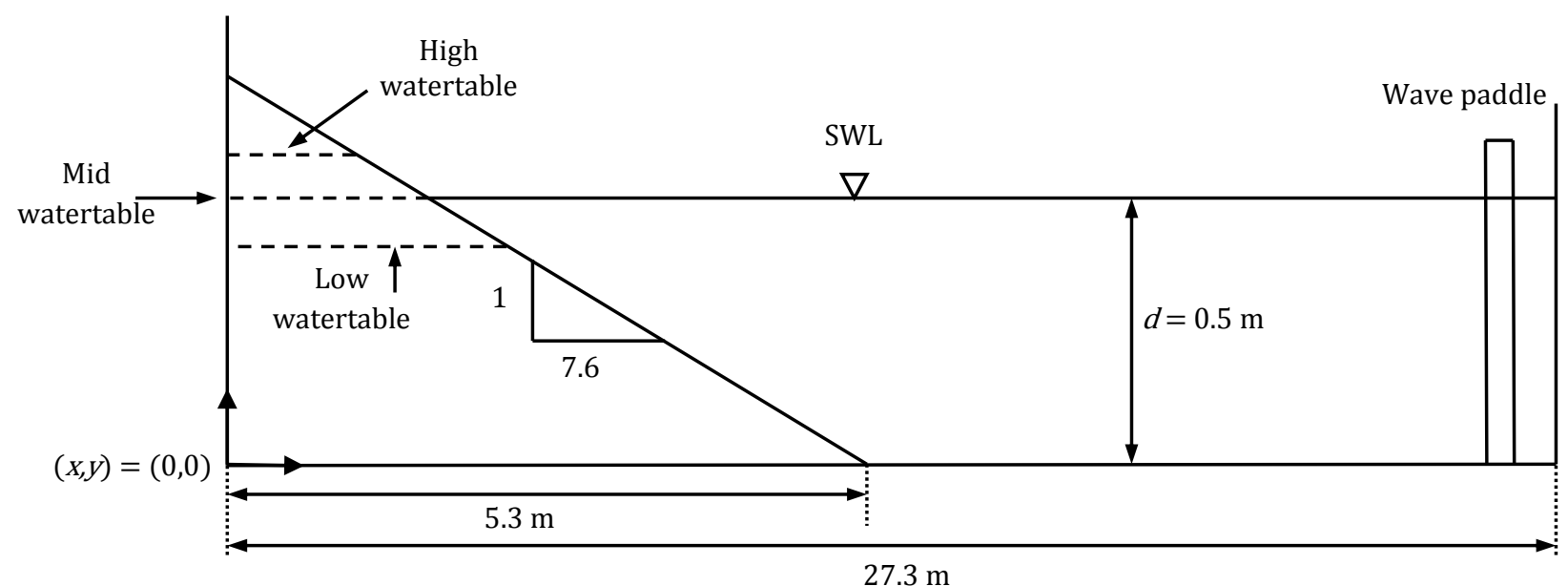

Fig. 2. Sketch of the set-up used in the experiments reported by Horn et al. [52] and in the numerical model described in this work. Freshwater is used throughout. Waves are generated in the free water section (right) and break on the sloping beach (left). At the left-hand end, the groundwater level is maintained at different positions corresponding to high, mid and low groundwater elevations. 


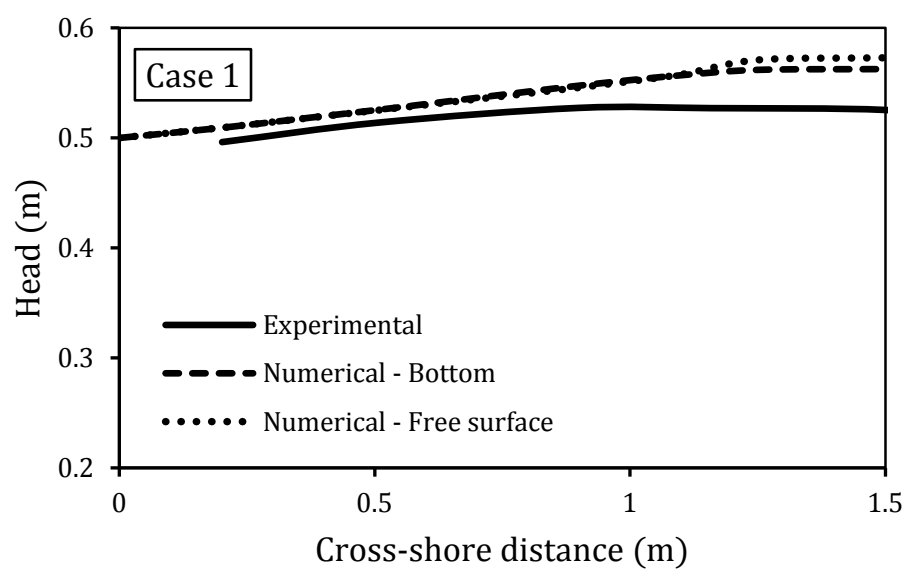

(a)

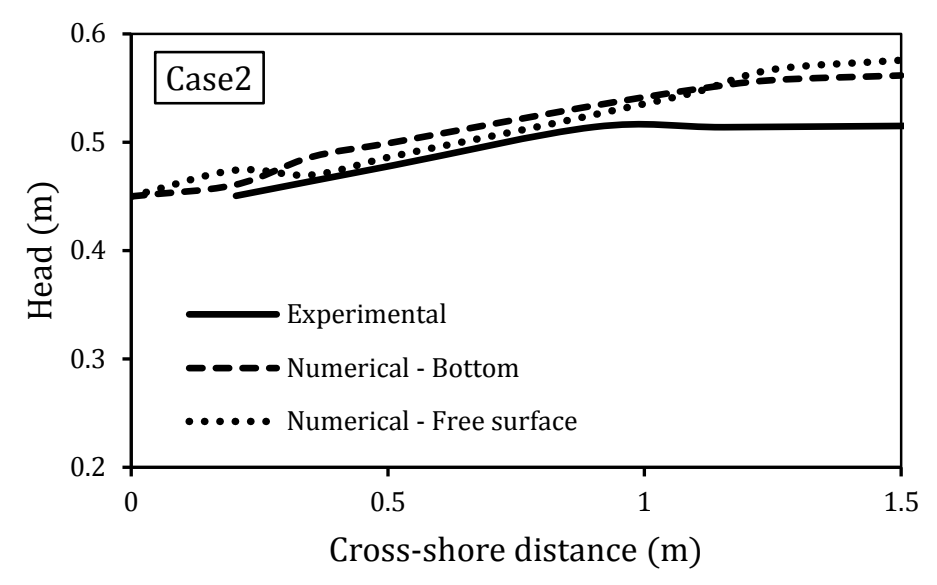

(b)

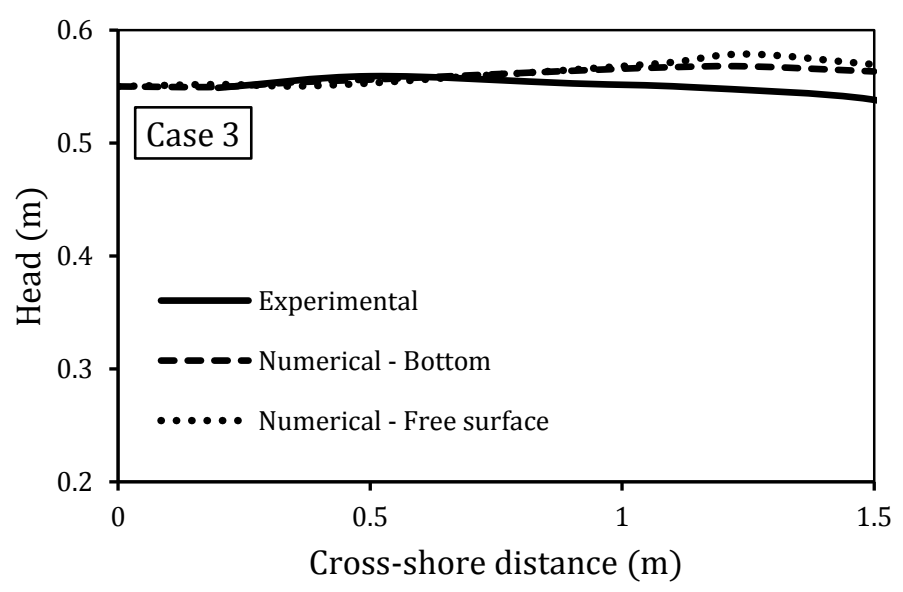

(c)

Fig. 3. Measured and modeled head levels on the fine sand beach for (a) the same, (b) lower and (c) higher watertable level. Cases are defined in Table 1. Dashed lines are the numerical results for free surface location, dots give the location of the free surface based on model-predicted pressures at the base of the experimental tank and assuming hydrostatic conditions at each measurement location, and solid lines are the experimental data of Horn et al. [52]. 


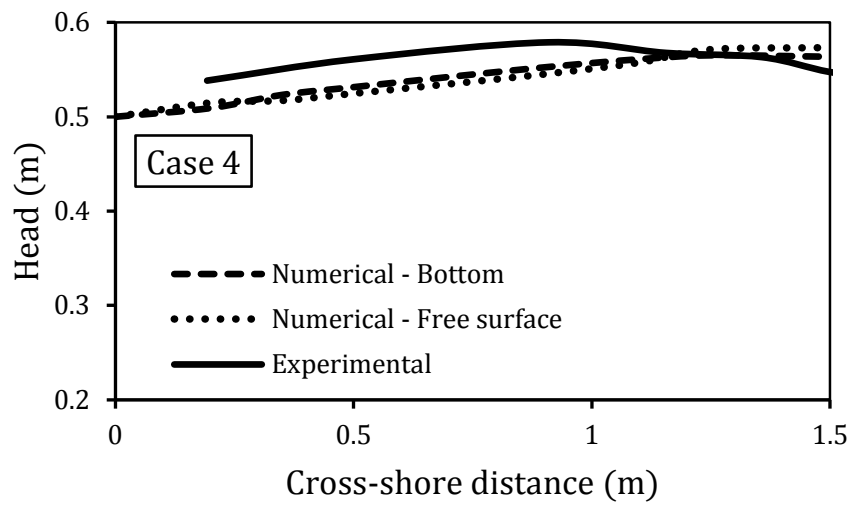

(a)

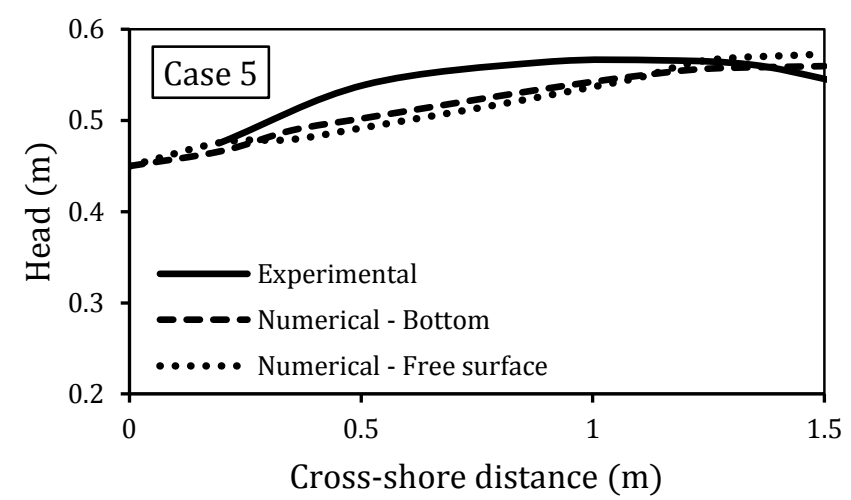

(b)

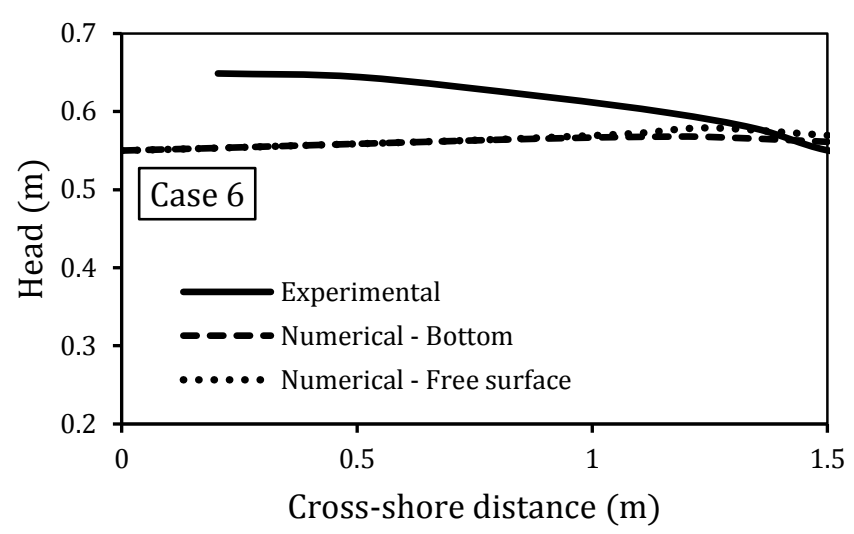

(c)

Fig. 4. Measured and modeled head levels on the coarse sand beach for (a) the same, (b) lower and (c) higher watertable level. Dashed lines are the numerical results for free surface location, dots give the location of the free surface based on model-predicted pressures at the base of the experimental tank and assuming hydrostatic conditions at each measurement location, and solid lines are the experimental data of Horn et al. [52]. 


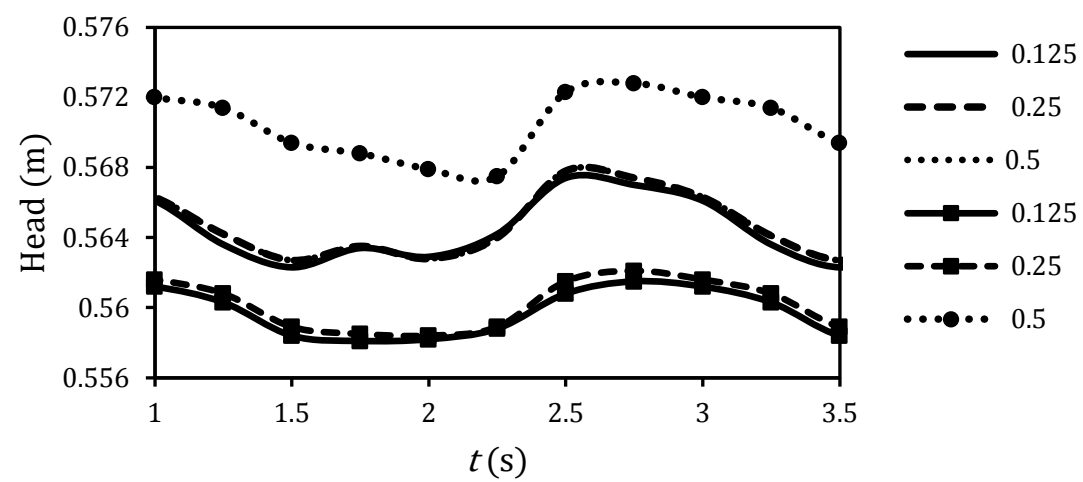

(a)

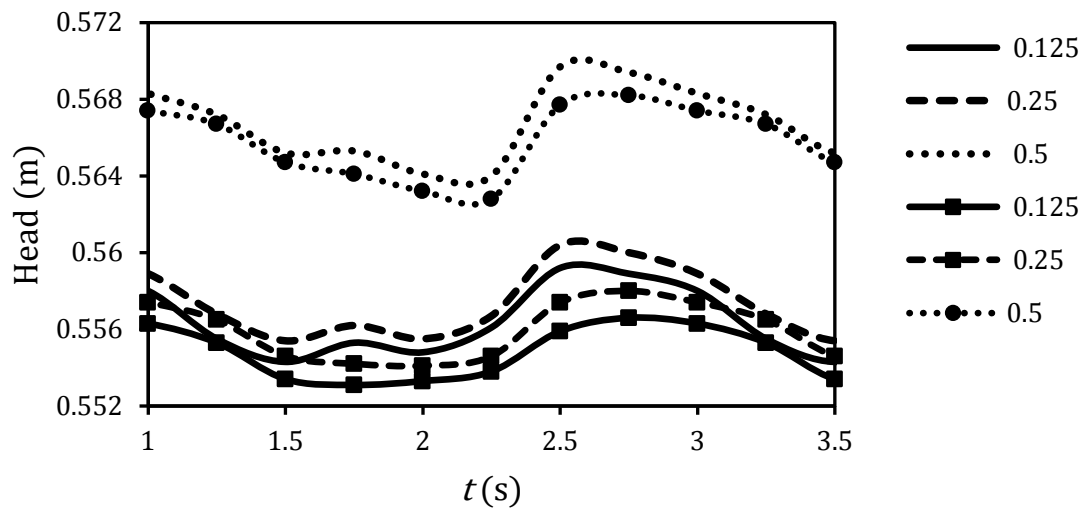

(b)

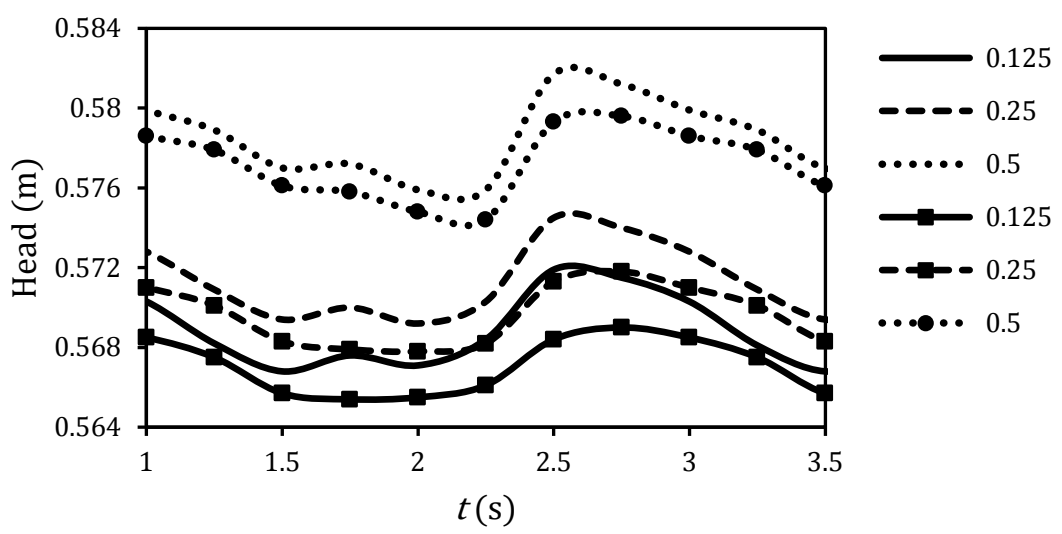

(c)

Fig. 5. Time variation of phase-averaged head at different depths (listed in the figure) and distance $x=1.25 \mathrm{~m}$ from the landward boundary for (a) same watertable and SWL, (b) lower watertable, and (c) higher watertable. Lines with symbols are the heads for fine sand beaches and lines without symbols are the heads for coarse sand beaches. 


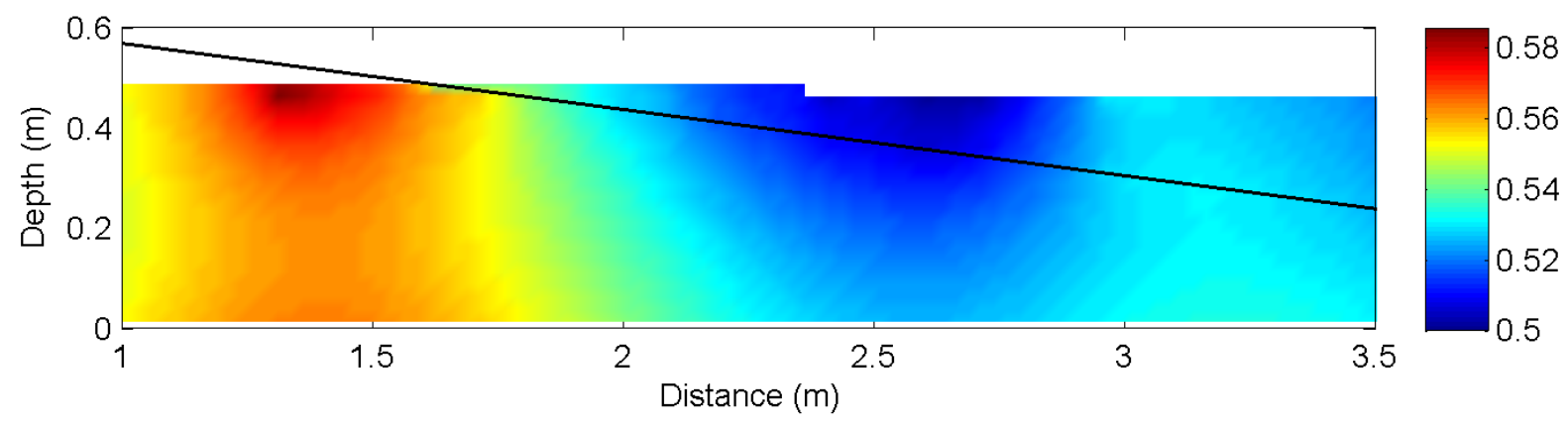

(a)

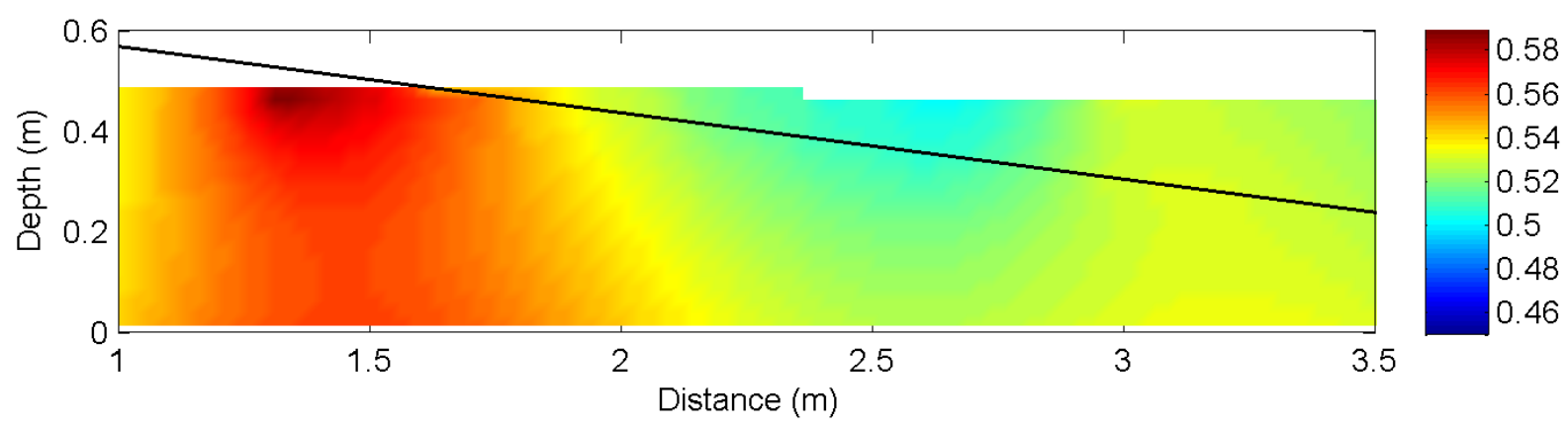

(b)

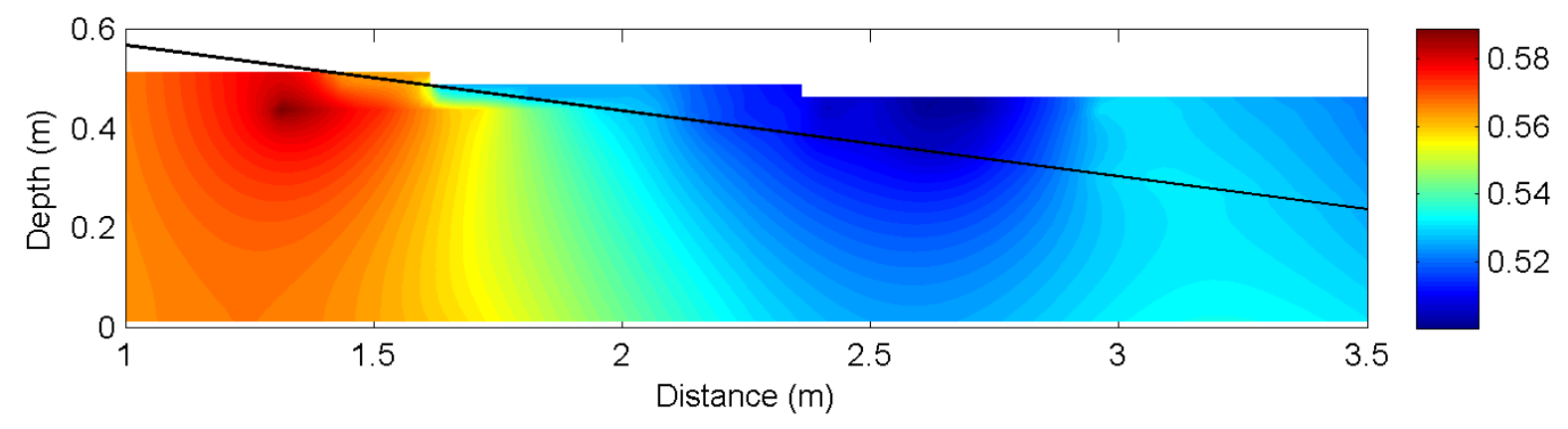

(c)

Fig. 6. Time-averaged heads in the nearshore aquifer for the fine sand beach for (a) the same, (b) lower and (c) higher watertable level.. Head units are in $\mathrm{m}$ 


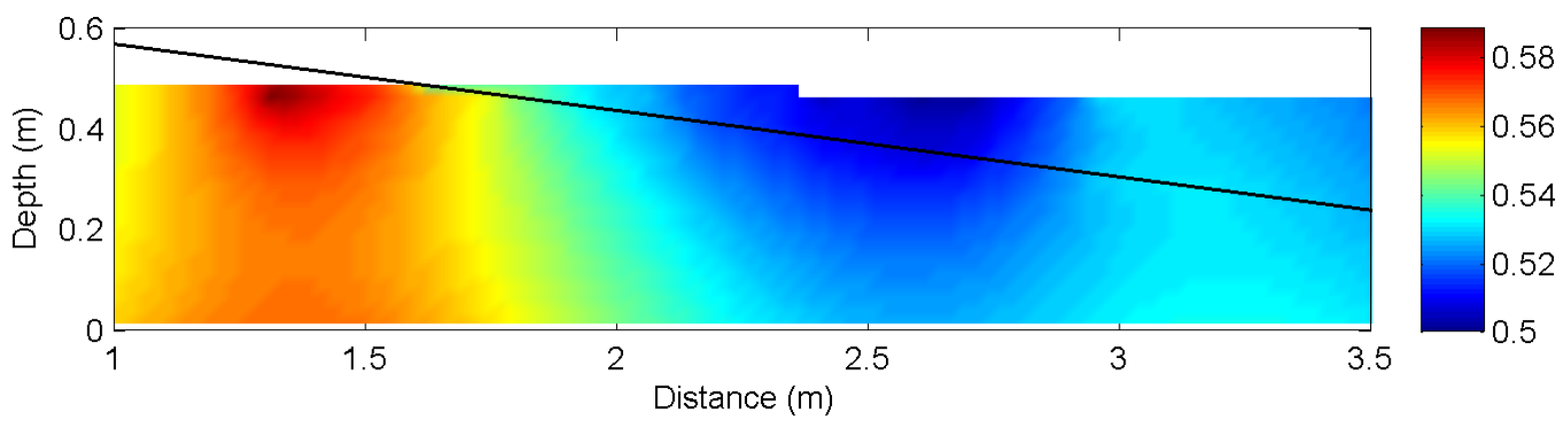

(a)

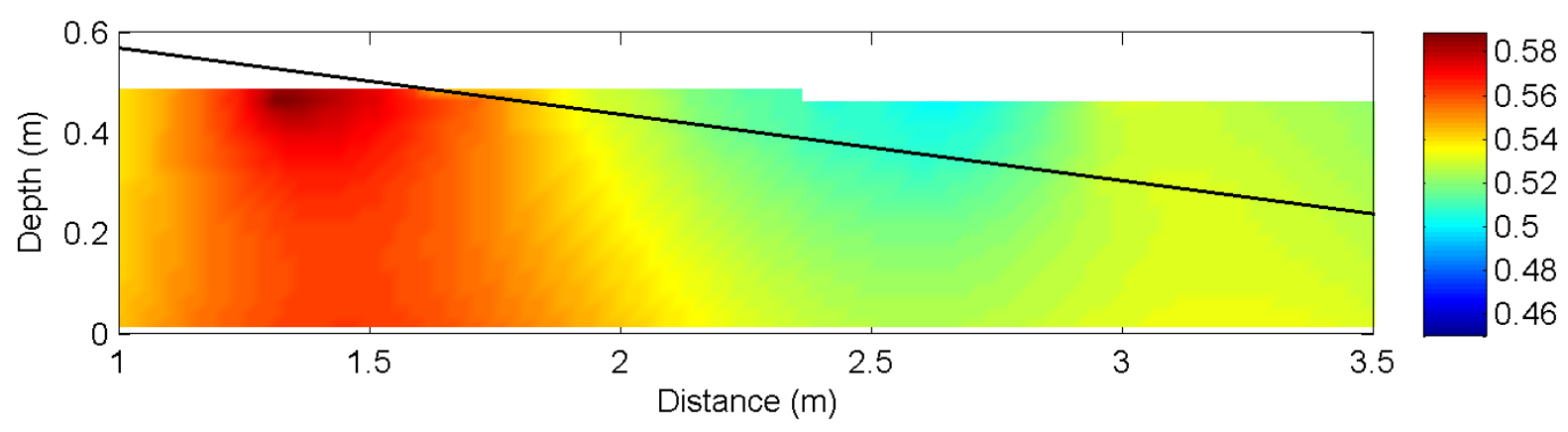

(b)

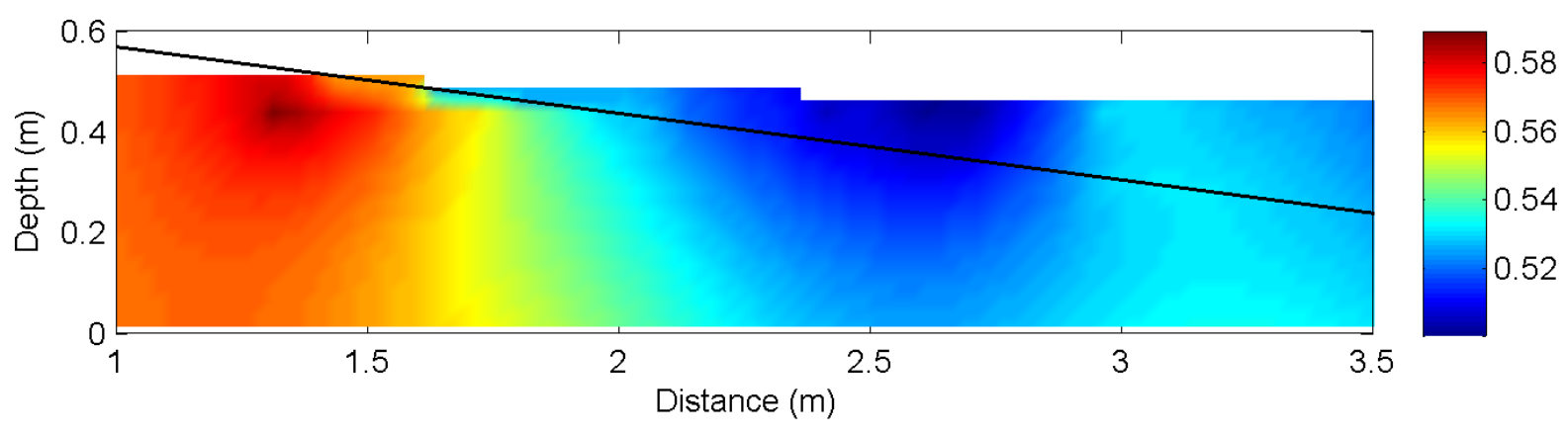

(c)

Fig. 7. Time-averaged heads in the nearshore aquifer for the coarse sand beach for (a) the same, (b) lower and (c) higher watertable level. Head units are in $\mathrm{m}$. 


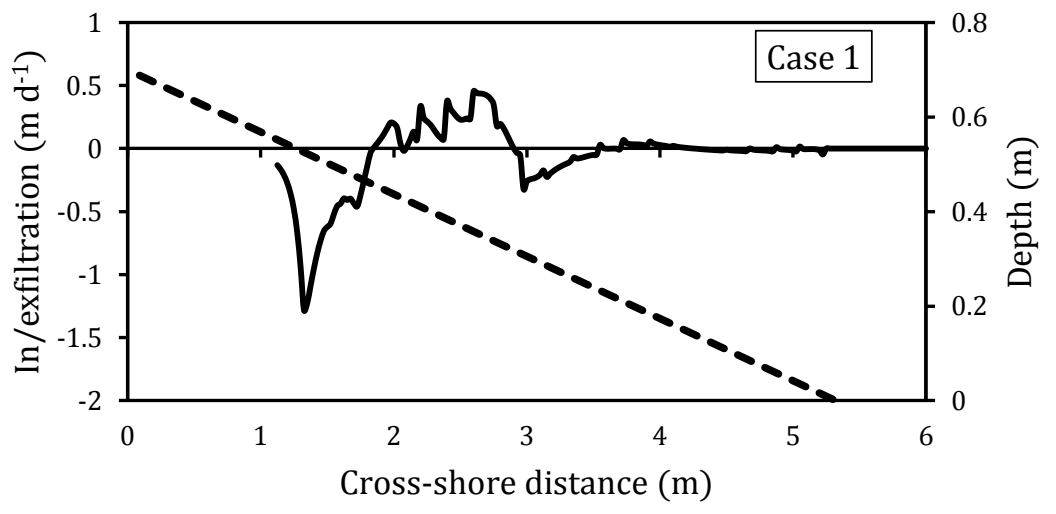

(a)

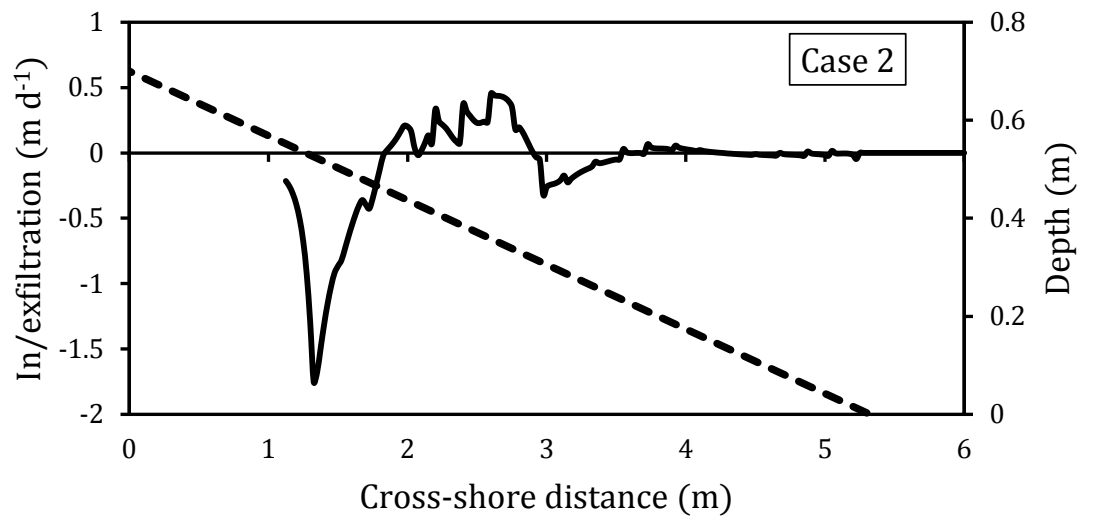

(b)

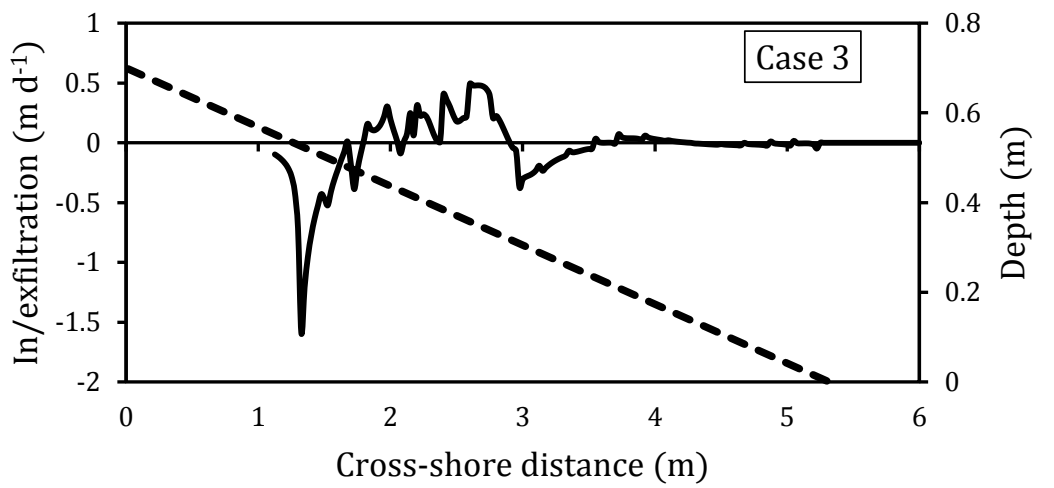

(c)

Fig. 8. Averaged infiltration/exfiltration rates on the beachface for the case with fine sand and groundwater elevation (a) the same, (b) lower and (c) higher than the SWL. The dashed-line shows the initial beach profile. For each plot, positive and negative values indicate the exfiltration and infiltration, respectively. 


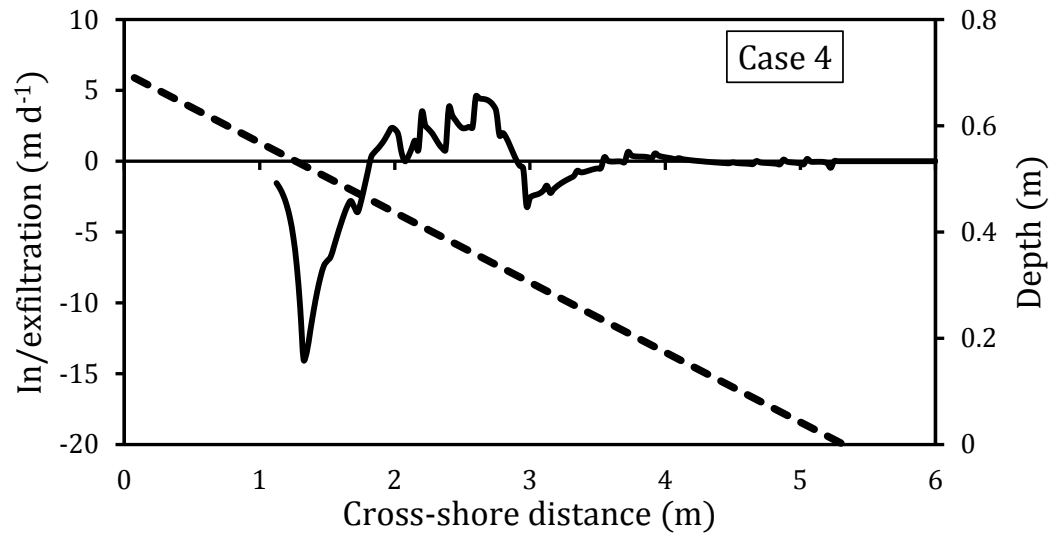

(a)

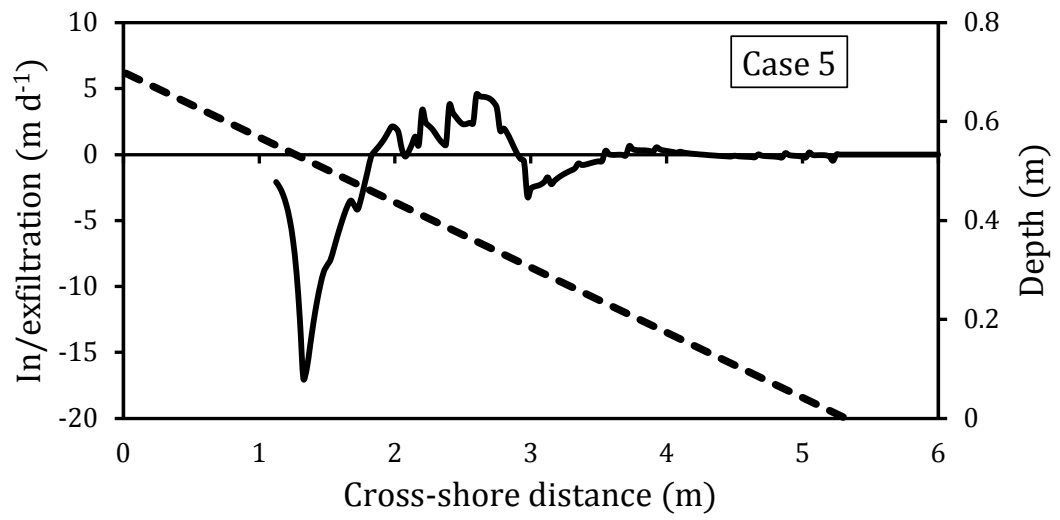

(b)

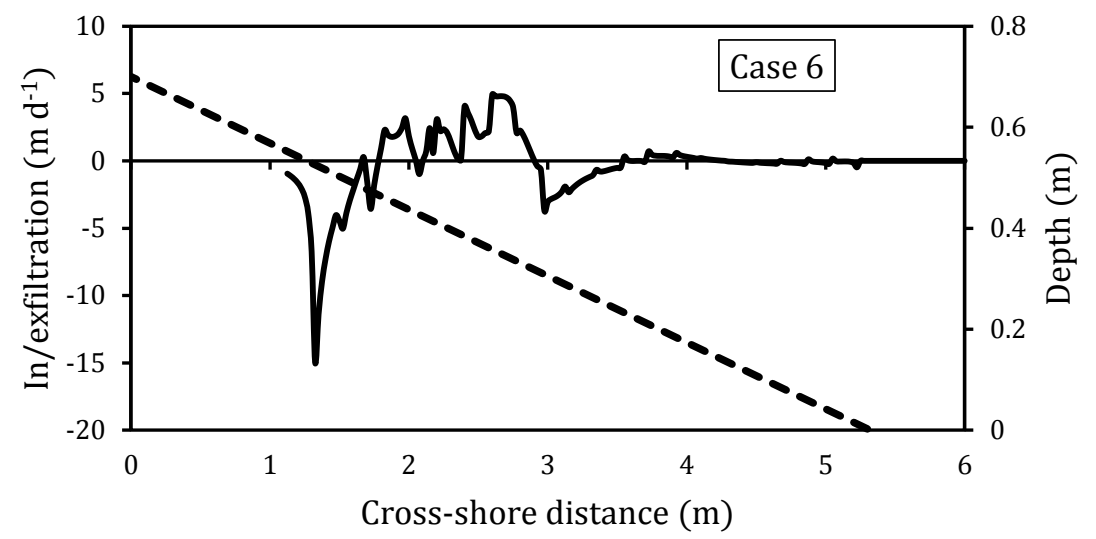

(c)

Fig. 9. Averaged infiltration/exfiltration rates on the beachface for the case with coarse sand and groundwater elevation (a) the same, (b) lower and (c) higher than the SWL. The dashed-line shows the initial beach profile. For each plot, positive and negative values indicate the exfiltration and infiltration, respectively. 


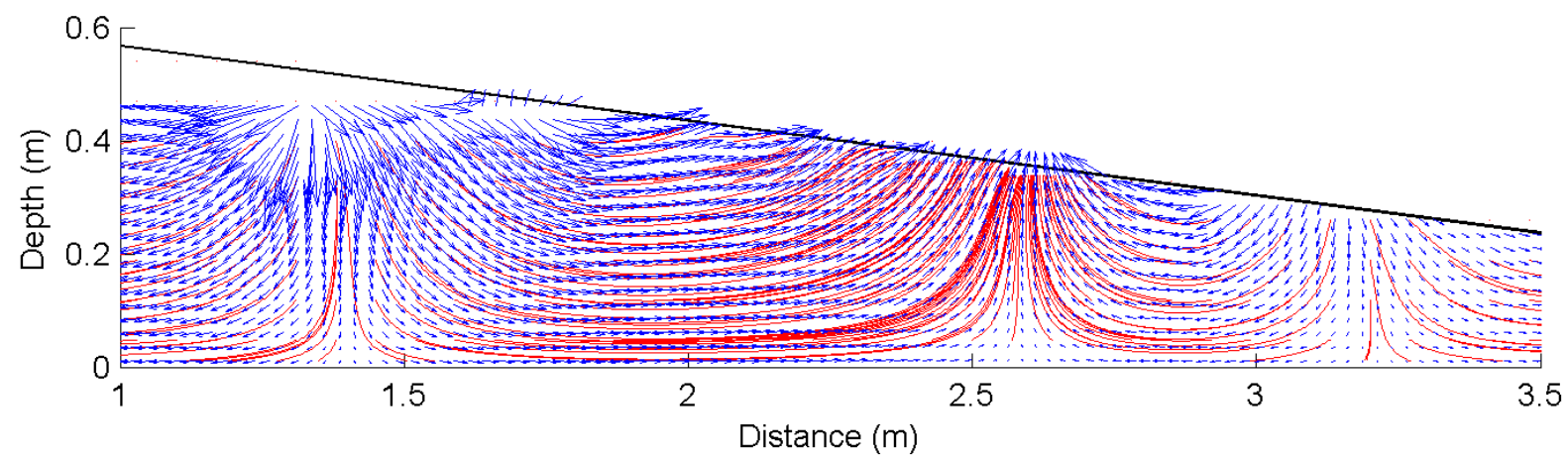

(a)

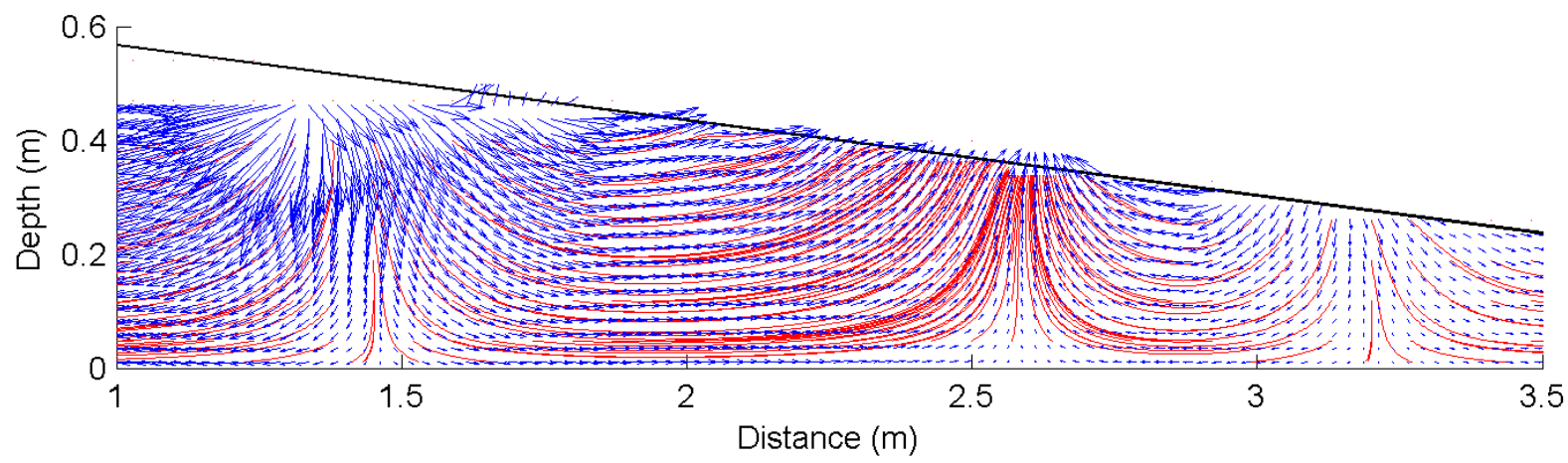

(b)

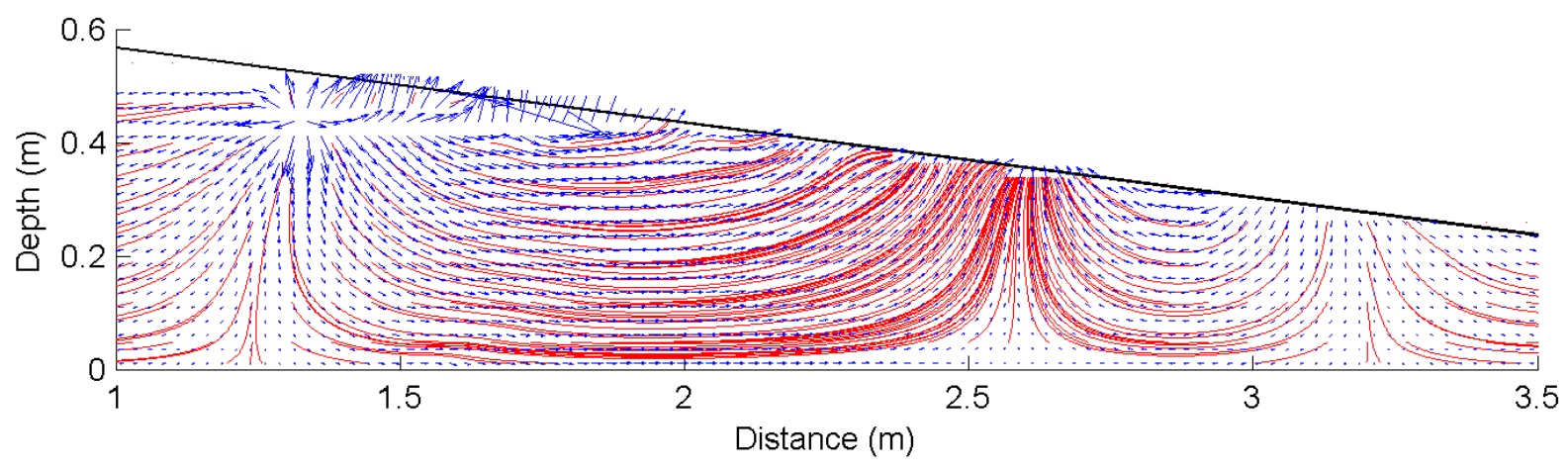

(c)

Fig. 10. Streamlines (in red) and velocity vectors (blue arrows) on the fine sand beach for (a) the same, (b) lower and (c) higher watertable levels. The length of the vectors is proportional to the magnitude of velocity. 


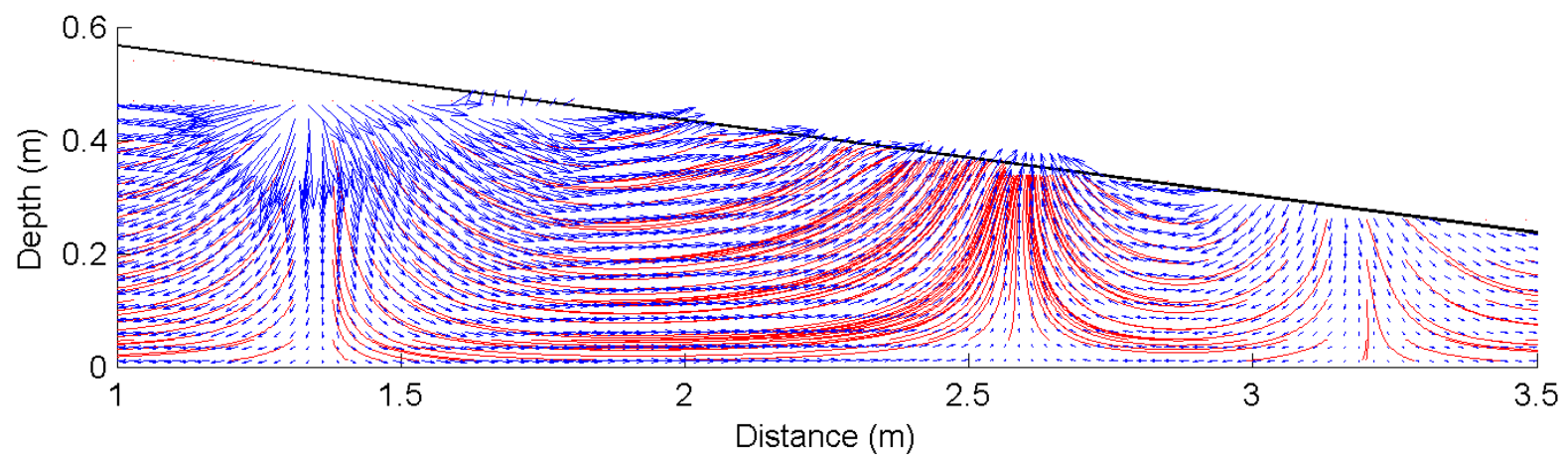

(a)

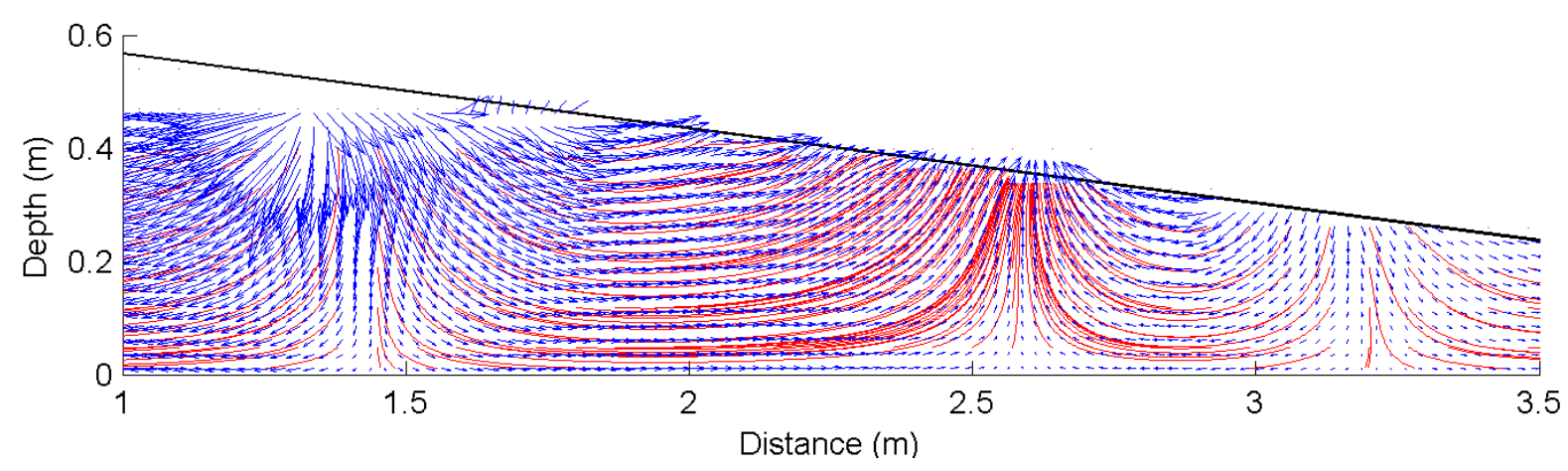

(b)

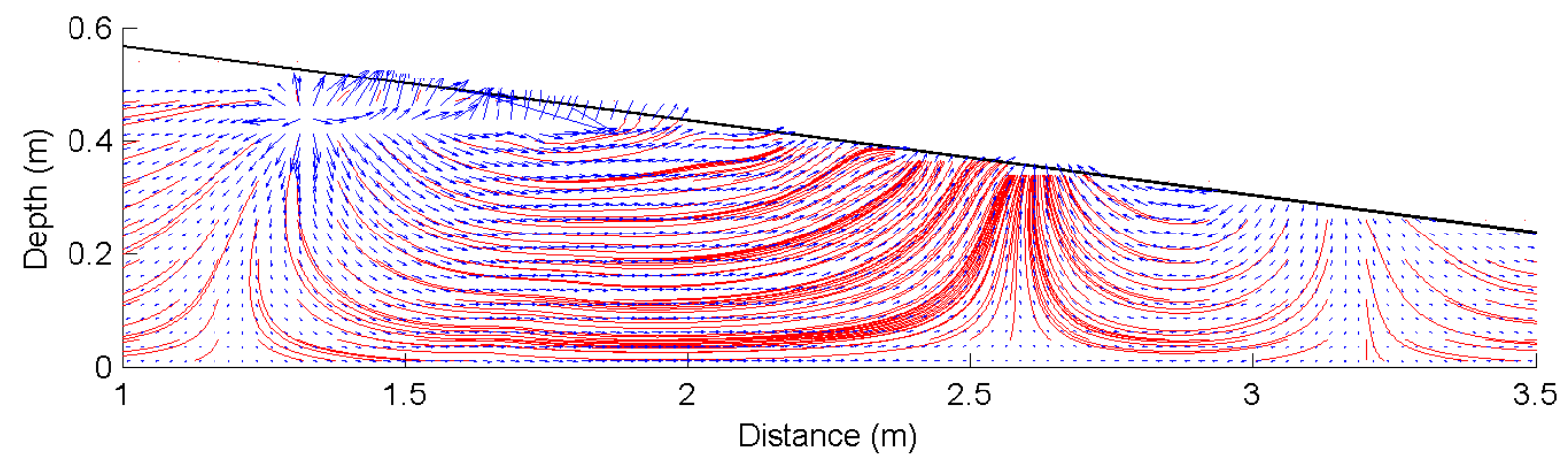

(c)

Fig. 11. Streamlines (in red) and velocity vectors (blue arrows) on the coarse sand beach for (a) the same, (b) lower and (c) higher watertable levels. The length of the vectors is proportional to the magnitude of velocity. 


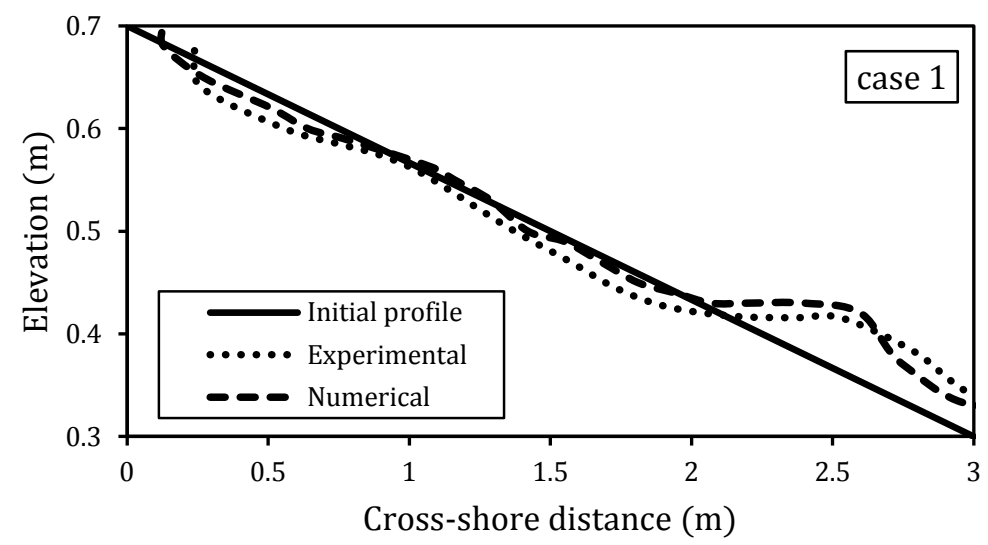

(a)

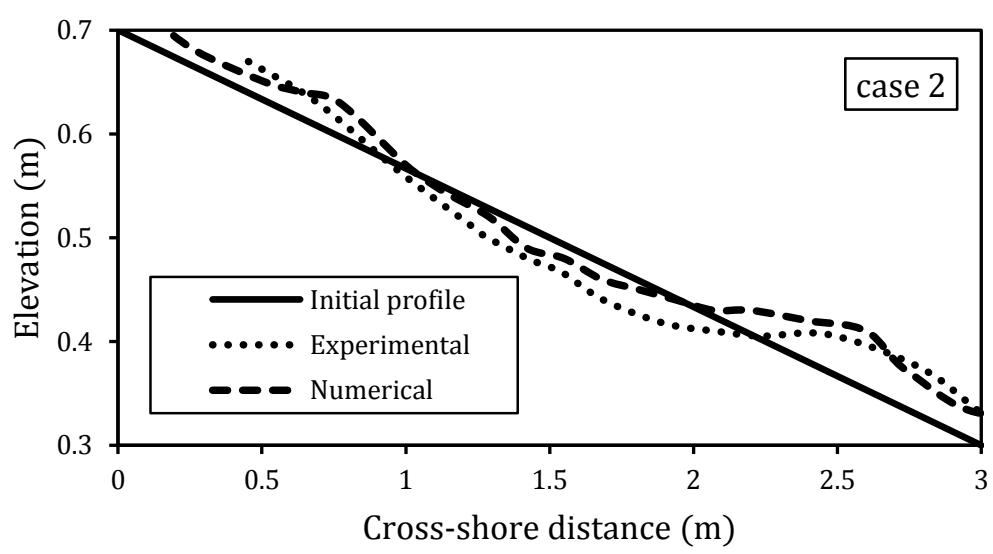

(b)

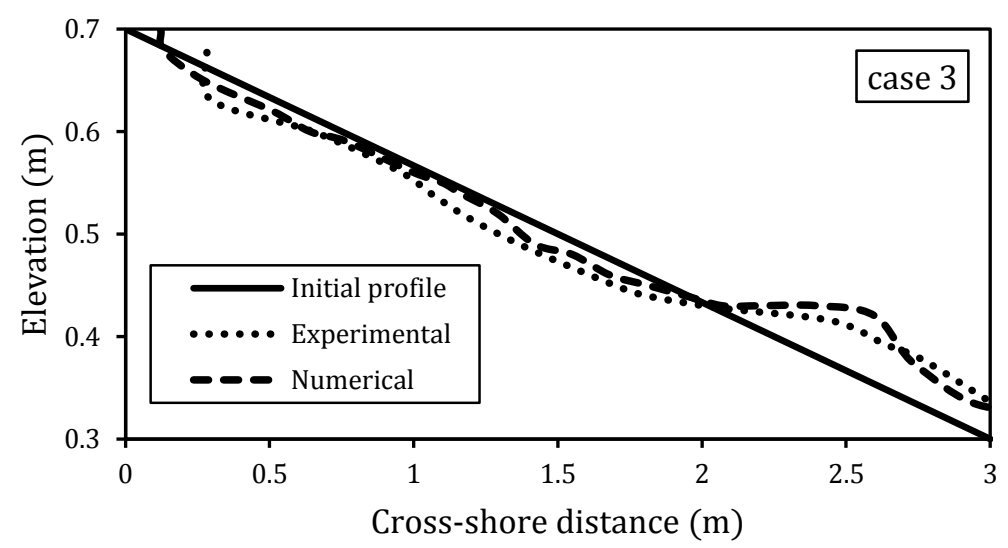

(c)

Fig. 12. Numerical results and experimental data [52] for foreshore profile evolution on the fine sand beach for (a) the same, (b) lower and (c) higher watertable level. 


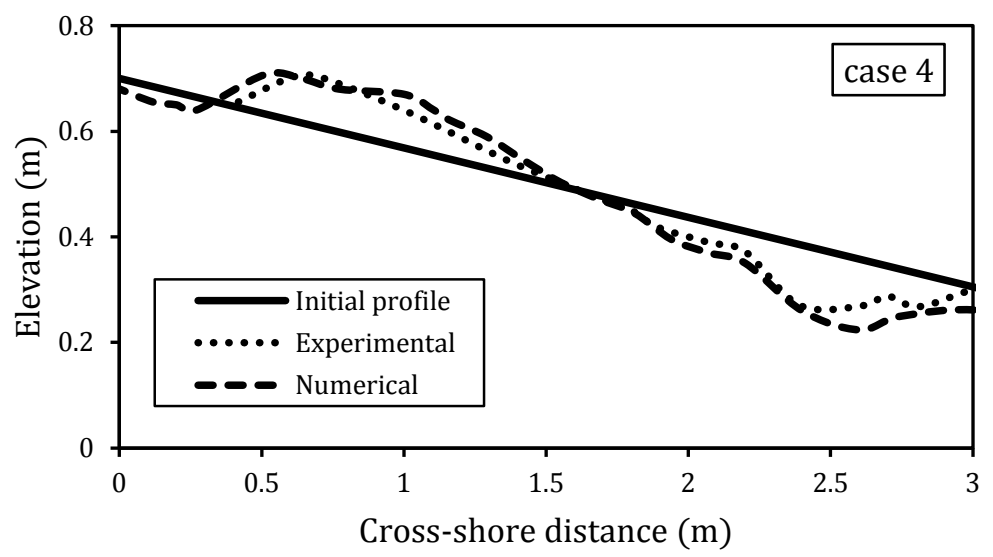

(a)

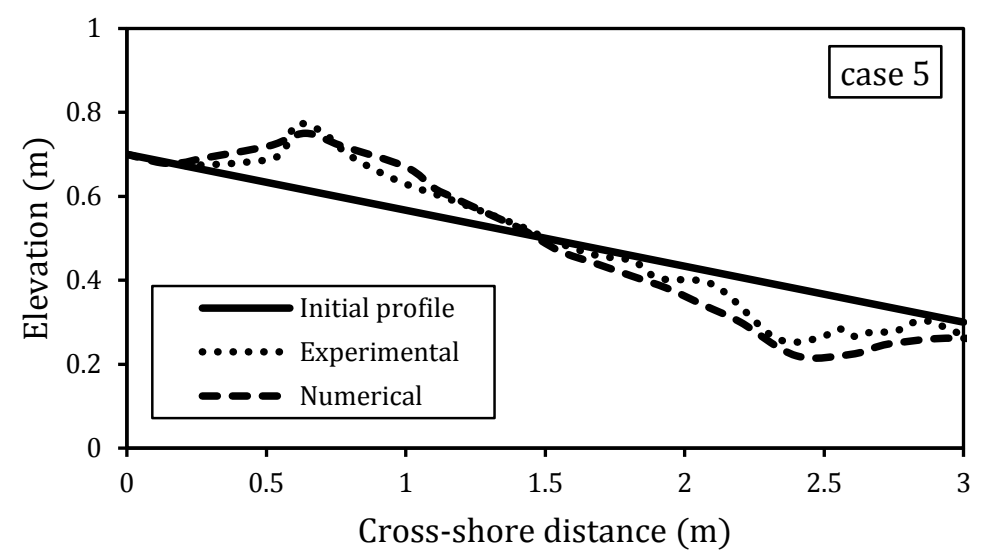

(b)

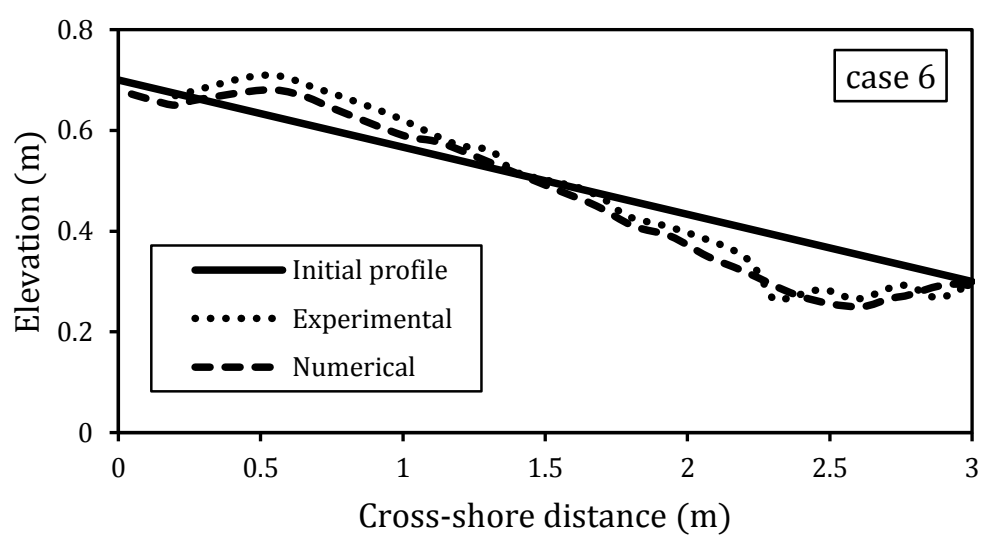

(c)

Fig. 13. Numerical results and experimental data [52] for foreshore profile evolution on the coarse sand beach for (a) the same, (b) lower and (c) higher watertable level. 


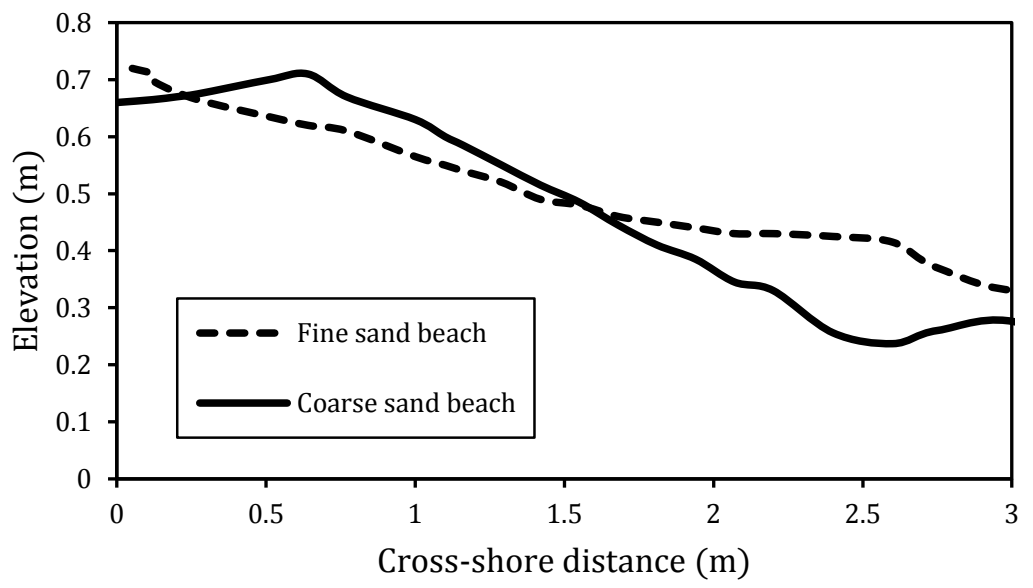

Fig. 14. Foreshore profile evolution on the fine and coarse sand beaches without groundwater effects. 